\title{
La Deuda Imperial y la Doctrina Republicana. Un momento en la historia de las relaciones México-Gran Bretaña, 1863-1867
}

\section{Silvestre Villegas Revueltas*}

Resumen

De acuerdo con el análisis elaborado por George White, agente de Baring, este artículo examina la situación de México en 1863 antes del establecimiento del Imperio de Maximiliano. Este trabajo analiza cómo la intervención francesa resultó en diferentes préstamos que incrementaron el monto de la deuda mexicana haciendo poco factible su pago puntual. También el artículo investiga sobre la estrategia diplomática republicana y el desarrollo de una política de Estado que se ha llamado la Doctrina Republicana que suspendió las relaciones con la Gran Bretaña.

\section{Abstract}

According to the analysis made by George White, agent of Baring, this article examines Mexico's situation in 1863 before the establishment of Maximilian's Empire. This work analyses how the French Intervention resulted in different loans that increased Mexico's debts to amounts impossible to be paid on time. The article investigates the republican diplomatic strategy and the developing of a state policy called the Republican Doctrine, which interrupted the relationship with Great Britain.
Palabras clave:

Deuda, banca, diplomacia, doctrina, legitimidad.
Fecha de recepción: abril de 2000

Fecha de aceptación: agosto de 2000

*Investigador de tiempo completo en el Instituto de Investigaciones Históricas-UNAM en el Área de México moderno: doctrinas políticas s. XIX, relaciones diplomáticas y financieras México-Gran Bretaña. 
"De todas las cosas más injustificables y más impolíticas es una intervención frustrada"

Sir. William Harcourt 1862.

$\mathbf{E}$ ste artículo no ha sido concebido como un estudio de los problemas políticos, ni de las estrategias militares desarrolladas por el ejército francés durante el Imperio de Maximiliano (1864-1867). Tampoco intenta explicar la resistencia republicana encabezada por Benito Juárez, ni la problemática relación entre el presidente y diversos gobernadores; el mejor ejemplo de la autonomía desarrollada por estos caciques regionales y locales. Tales asuntos han sido ya bastante analizados desde la época del triunfo republicano, hasta en la literatura reciente por medio de famosos y bien conocidos estudios. ${ }^{1}$ Primeramente, este artículo examinará la visión de George White sobre México en 1863, previa al establecimiento del Imperio de Maximiliano. En segundo lugar se verá cómo la intervención francesa dio como resultado la promoción de diferentes préstamos soberanos que dieron existencia al Segundo Imperio, teniendo como consecuencia un proceso de nuevas obligaciones financieras, las cuales incrementaron los montos de la deuda mexicana que hicieron poco factible el ser abonadas puntualmente. Esta última cuestión puso en peligro la existencia del mismo imperio, más aún, tal endeudamiento e incapacidad para pagar resultó en una contradicción

Sierra, Juárez, 1977; Roeder, Juárez, 1984; Vigil, México, 1981, tomos Ix y x; Conte, Maximiliano, 1944; Bulnes, Verdadero, 1904; Galeana, Relaciones, 1991; Hamnett, Juárez, 1994. respecto a las razones financieras promovidas por los acreedores y por los gobiernos europeos, en el sentido de establecer un gobierno capaz de enfrentar sus compromisos internacionales. En tercer lugar, el presente estudio analiza la estrategia diplomática republicana para asegurar, entre otras cosas, que el gobierno de Estados Unidos nunca reconociera al imperio. La consecuencia de dicho reconocimiento a favor del emperador Maximiliano otorgado por Francia, Gran Bretaña, España, Bélgica, Austria y otros Estados, aunado a la victoria obtenida por los republicanos, dejó al gobierno de Benito Juárez en la capacidad de desarrollar una política de Estado, la cual fue denominada como la Doctrina Republicana. Ésta suspendió la relación diplomática entre México y las potencias europeas. Más importante, cambió la naturaleza de la deuda externa de México y su relación con los acreedores extranjeros.

\section{La SITUACión DE MÉxico en 1863}

La suspensión diplomática unilateral iniciada por Charles Wyke en julio de 1861 no fue una ruptura total, porque las relaciones bilaterales continuaron con el fin de resolver la suspensión de pagos y el reconocimiento de las reclamaciones británicas. Las negociaciones mexicanas querían evitar que la Gran Bretaña continuara apoyando el proyecto intervencionista francés. Pero cuando el gobierno de Palmerston se negó a reconocer la Convención de Puebla (mayo de 1862), y cuando Wyke fue advertido de no seguir fuera de la ciu- 
dad de México en la administración de Juárez, se puede decir que la ruptura entre ambos gobiernos fue un hecho. Más aún, la ruptura unilateral se hizo más evidente porque el siguiente ministro residente en México representaba al Reino Unido ante la corte de Maximiliano, quien fue recibido en enero de 1865. Por otro lado, los tenedores de bonos de Londres y aquellos de la Convención Inglesa comprendieron que la intervención militar francesa en México estaba creando diversos intereses financieros europeos diferentes a ellos. Estos elementos fueron materia de confrontación a lo largo de 1862 y 1863 , pero el enfrentamiento más serio se desarrolló a lo largo de los años setenta hasta 1886. Los acreedores británicos decidieron intervenir directamente en las negociaciones con las autoridades mexicanas informándoles que el Comité de Tenedores de Bonos Mexicanos había decidido contratar nuevamente al banco Baring, como la institución responsable de proteger y representar los intereses de los acreedores de México. ${ }^{2}$

${ }^{2}$ Chapman, Rise, 1984. Tomás Baring III era descrito como inteligente y con ideas claras para realizar operaciones crediticias que implicaban riesgos. Más aún, era considerado como un príncipe del mercado y un digno sucesor de los $\mathrm{Me}$ dicis o los Fuffer (ver p. 28). Chapman resalta que un amigo cercano de Baring en la City era Bertran Currie del banco Glyn Mills, al mismo tiempo su principal conexión en París era Rodolfo Hottinger. Estos dos últimos nombres son muy importantes porque los dos banqueros participaron en los préstamos de 1864 y 1865 otorgados al archiduque Maximiliano. Igualmente, porque a partir de 1884 Glyn Mills, Currie y Cía. se convirtieron en los agentes del gobierno mexicanos y del Banco Nacional de México, encargados
Este artículo considera primordial exponer el siguiente análisis de la situación social y financiera de México en 1863 , como una visión de la república, su población y el último balance de la deuda mexicana previo a los préstamos contratados en Londres y París para establecer el Imperio de Maximiliano.

\section{El análisis de George White}

En febrero, George White, el recién nombrado agente de Baring Bros. en la ciudad de México, informó al banco que la mayoría de los intereses involucrados en las reclamaciones británicas

de remitir los pagos al Consejo de Tenedores de Bonos Extranjeros. Las cartas, reportes y otros materiales históricos usados en el presente artículo me fueron prestados por el doctor John Orbell, jefe del Archivo de INGBaring en Londres. Véase, Orbell, Baring, 1985; Guide, 1997; Presnell y Orbell, Guide, 1985; Baring, 1970; Rowsley, Going, 1996. Durante el siglo XIX, Baring fue en conjunción con Rothschild en Brasil la más importante casa bancaria, especializada en préstamos a América Latina y en la producción de plata. En México, después de que el gobierno contrató los préstamos de 1824 y 1825 con Goldschmidt y luego con Barclay \& Richardson, Alexander Baring desarrolló importantes intereses en el país, al mismo tiempo fue agente del gobierno mexicano, pero igualmente protegió los intereses de los tenedores de bonos de Londres y de la Convención Inglesa. Muchas veces los intereses de la City consideraron a Baring como un experto en asunto sobre México. Tiempo después otros bancos mercantiles como Glyn Mills y Antony Gibbs se convirtieron en los más importantes acreedores de la república. Actualmente el banco Baring es solamente un nombre de ING de Holanda, uno de los grandes consorcios del mundo. 
contra México no pertenecían a súbditos ingleses. ${ }^{3}$ Sin embargo, apuntaba que, como resultado de las diversas suspensiones de pagos y de las pérdidas acumuladas por los largos años de revoluciones y de sublevaciones militares, el gobierno británico finalmente había quedado involucrado en dicha cuestión y en garantizar el cumplimiento de las convenciones diplomáticas entre ambos países. ${ }^{4} \mathrm{El}$ reporte de White coincidía con los estudios hechos por Percy Doyle, en los años cincuenta, sobre las cuentas de George Mathew, que daba razón de las consecuencias del triunfo liberal (18601861) y concordaba con los despachos de Charles Wyke dirigidos a John Russell (1861-1862).

Tras cuatro meses de haber vivido en la república, White envió a Thomas Baring seis documentos relativos a la sociedad, la naturaleza, el comercio y el sistema político prevaleciente en México, desde los tiempos de la guerra de Independencia hasta ese momento. Más de la mitad de sus notas tenían observaciones específicas sobre diversos problemas esenciales, como la conformación social del país, la producción de oro y plata, el comercio, la hacienda pública y el sujeto principal de su misión: la deuda externa. Estos documentos no han sido estudiados

${ }^{3}$ Tenenbaum, “Mexico's”, 1995, pp. 257-292. Tenenbaum ha reconocido la nacionalidad de los reclamos: diez mexicanos, cinco ingleses/irlandeses, seis franceses/suizos/alemanes, cinco otros países.

${ }^{4}$ George White a Thomas Baring, México, 17 de febrero de 1863 en Baring House Correspondence (en adelante $\mathrm{HC}$ ), HC.4.5.35. por los especialistas del Imperio de Maximiliano, sin embargo, los reportes de White han sido analizados por John Orbell en un libro sobre los viajeros que en el siglo XIX visitaron México. Una perspectiva distinta a la de esta investigación. ${ }^{5}$

El inglés consideraba que la población nativa era el principal problema de México: más de 60\% eran indios, gente "completamente desprovista de imaginación", incapaces de actuar en un momento de emergencia. Indicaba que su actitud había sido la de sentarse y dejar que las cosas tomen su curso. Las cualidades de los indios educados:

\begin{abstract}
llevan a una cercana remembranza de los descendientes de la raza española; manifiestan el mismo celo y odio a los extranjeros, la misma traición, el mismo desdén a sus promesas y compromisos, la misma insolencia cuando tienen poder, el mismo servilismo cuando se encuentran en adversidad[...] Sin embargo, su antipatía a los extranjeros, a toda persona de complexión europea, no involucra una simpatía activa con su misma raza."
\end{abstract}

Los conceptos que White tenía sobre México revelan una mezcla de información real y de prejuicios, sobre una sociedad totalmente diferente a la suya. El agente de Baring consideraba que, después de 40 años de caos, los mexicanos habían probado su incapacidad para administrar y resolver los problemas de la república. Los intere-

3 Orbell, "George ", 1996, pp. 95-98; Quirarte, Historiografía, 1993.

6 White, "Notes in the Present State of Society in Mexico", en HC. 4.5.36. [1]. 
ses económicos de las naciones industrializadas necesitaban imponer orden en el país y, en consecuencia, el proceder más adecuado era el de apoyar el establecimiento de un gobierno fuerte. El requisito, la ayuda externa, y el vehículo, una inmigración industriosa, "el plan, reemplazar a la estéril raza latina". ${ }^{7}$ Por medio de estos cambios México se convertiría en una nación solvente y respetable.

Antes de que el gobierno de Juárez tuviera que cambiar su residencia a San Luis Potosí como resultado de la caída de Puebla y del inminente sitio francés contra la ciudad de México, White envió otro documento intitulado Observaciones generales sobre las finanzas mexicanas. El consideraba que no importaba el partido político que hubiera estado en el poder, ni los principios o las promesas que pudiera haber hecho. La pauta de los gobiernos mexicanos había sido "la determinación de no pagar ninguna deuda a excepción de aquéllas como resultado del uso de la fuerza". ${ }^{8} \mathrm{El}$ agente hizo hincapié en un problema verdadero: los ministros de finanzas mexicanos, aun siendo honestos, no encontraban la manera de resolver el problema del servicio de la deuda. Lo anterior, era el resultado de una confusa y prolífica legislación, aunado a diversas obstrucciones promovidas por grupos de intereses a lo largo del país. Señalaba que durante décadas, especuladores, empleados públicos y gobernadores de los estados ha-

7 lbid.

8 White, "General Observations on Mexican Finance", en HC.4.5.36.[2]. bían estado robando al país. La constitución política de la república había instituido el sistema federal de gobierno, sin embargo, el poder ejecutivo solamente tenía un control nominal sobre los estados y sobre los ingresos federales recolectados en tales entidades. Tal anormal condición había generado desórdenes y había dado como resultado que los gobernadores estatales incumplieran las estipulaciones fiscales ordenadas desde la ciudad de México.

Las observaciones de White acerca del enfrentamiento entre la administración federal y la autonomía desarrollada por las autoridades locales, reproducen la tónica de los reportes elaborados previamente por otros agentes financieros, diplomáticos y también por diversos políticos mexicanos. Es indispensable considerar que esta conflictiva realidad ha sido identificada, en el análisis del siglo XIX mexicano, como el antagonismo entre el centro y las localidades, más aún, como la oposición entre gobiernos "nacionales" carentes de poder y vigorosos caciques regionales y locales. Esta última situación no solamente generó daños en contra de la vida y propiedades en manos de extranjeros y mexicanos, sino en particular, la inestabilidad política produjo la inobservancia de la legislación, en particular la del servicio de la deuda, que era el resultado de intensas negociaciones entre México y las potencias europeàs.

White caracterizó los más importantes problemas financieros de México como sigue: los gobiernos mexicanos han tenido que arreglárselas con los bajos precios de los bonos emitidos 
para pagar la deuda. Desde 1828, tales regímenes han adoptado el pernicioso sistema de despilfarrar futuros ingresos para obtener pequeños avances en efectivo. Por otro lado, el contrabando y otros fraudes en la administración de las aduanas han tenido como resultado una disminución de las rentas federales. Asimismo, los frecuentes levantamientos militares y la autonomía de que han gozado los gobernadores y las autoridades locales, han tenido como consecuencia el establecimiento de un sistema de préstamos forzosos y otros mecanismos arbitrarios para recolectar. dinero. Lo anterior ha dado como resultado que las administraciones mexicanas enfrenten una acumulación de numerosas reclamaciones privadas.?

Asimismo, White subrayaba que los gobiernos mexicanos tampoco tenían una idea precisa de las cantidades producidas por las minas, pero la exportación de plata, tanto en barras como en moneda, tendía a ser comparable o mayor a la de los tiempos de la administración española. ${ }^{10}$ Todas estas particularidades resultaron en un caos económico, en la disminución del comercio bilateral y, en consecuencia, el Estado mexicano empezó a tecibir cada vez menores cantidades vía impuestos. Las tarifas por concepto de importación y exportación habían sido el recurso reconocido por los tratados internacionales vigentes para solucionar el pago de la deuda externa.

White terminaba su análisis remarcando que los súbditos británicos no

\footnotetext{
9 Ibid.

${ }^{10}$ White, "Silver and Gold under the Spanish Administration", en HC.4.5.36.[3].
}

querían invertir más dinero en México a consecuencia de los problemas políticos, de los préstamos forzosos y de las intermitentes suspensiones de pagos realizadas por los gobiernos mexicanos. Finalmente, resaltó las siguientes premisas: los inversionistas requieren que haya en México estabilidad política, seguridad para la inversión y una reducción en las tarifas arancelarias. ${ }^{11}$

Teniendo en cuenta el papel rector jugado por Baring Bros desde 1828, unificando a los tenedores de los bonos Goldschmidt y Barclay en un solo fondo llamado la Deuda de Londres, tiempo después representando a los tenedores de bonos de Londres y de la Convención Inglesa, y finalmente considerando las recomendaciones de George White, este estudio coincide con las ideas propuestas por P. Cain y A. Hopkins en su libro acerca del imperialismo británico. Los dos autores argumentan que fueron los bancos mercantiles o imperiales quienes, usando los depósitos locales, ampliaron el crédito comercial y difundieron de esta forma el mercado británico. La City de Londres estaba especialmente interesada en las finanzas como un modo de influencia planetaria. La idea era integrar una economía internacional bajo la dirección de la Gran Bretaña. ${ }^{12} \mathrm{La}$ influencia de los banqueros ingleses, la de la bolsa de valores de Londres y los diversos intereses de la City, tales como los comités y luego el Consejo de Tenedores de Bonos Extranjeros, más que la burguesía industrial, fueron los grupos

\footnotetext{
11 Ibid.

12 Cain y Hopkins, British, 1993, p. 272.
} 
SECUENCIA

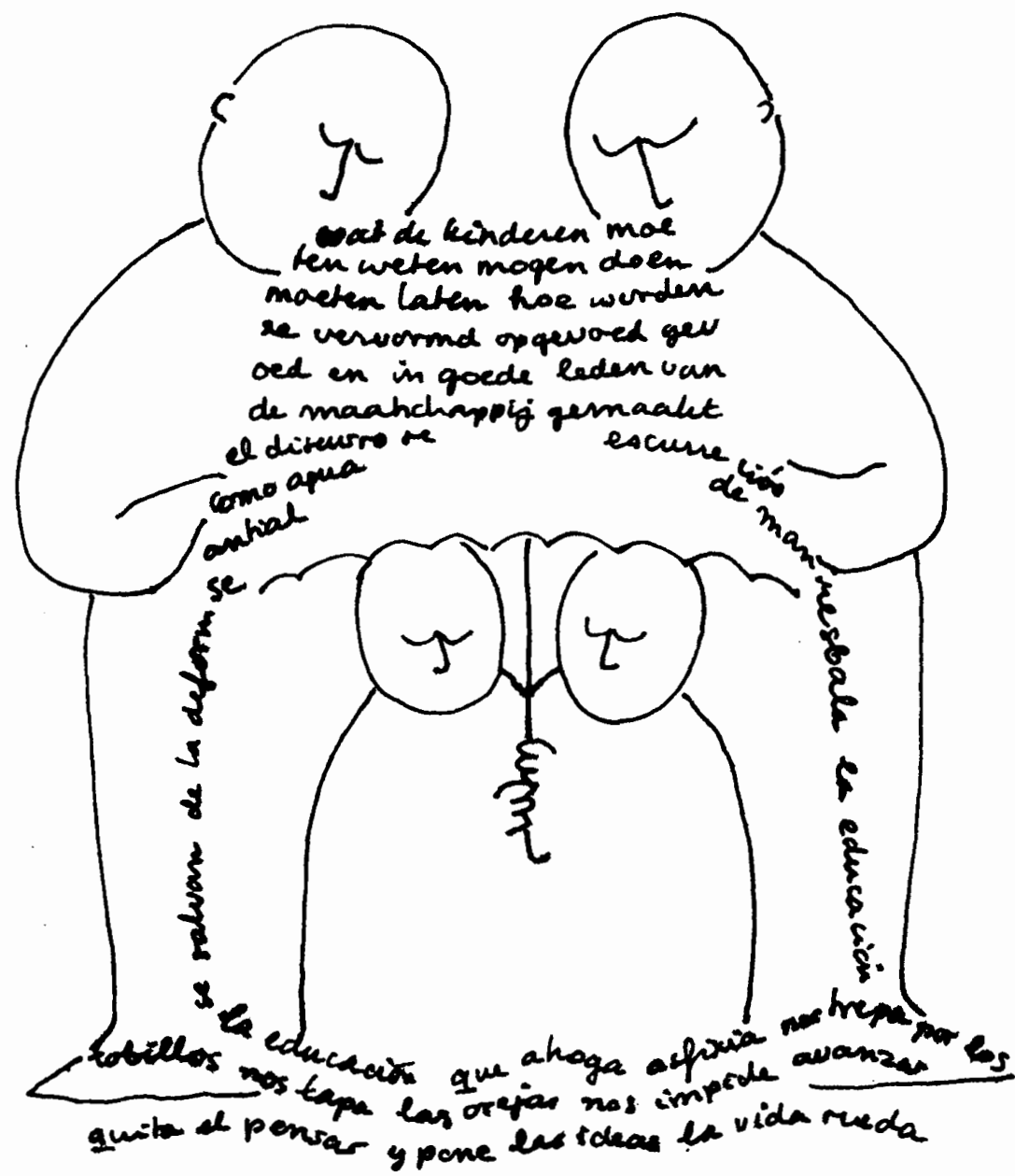


que ejercieron mayor presión sobre los asuntos políticos locales e internacionales de la Gran Bretaña. ${ }^{13}$ Desde la segunda mitad del siglo XIX, fueron los intereses financieros quienes progresivamente influyeron en las políticas oficiales británicas, con la idea de crear nuevas áreas de inversión, y promovieron que se brindara una tajante protección a inversiones en países problemáticos y distantes, como era el caso de México.

Tomando en cuenta las ideas de Cain y Hopkins es importante subrayar que, entre 1827 y 1830 , Alexander Baring había advertido a los tenedores de bonos mexicanos y latinoamericanos que, como resultado de las exorbitantes comisiones deducidas a los primeros préstamos soberanos y de las dificultades financieras experimentadas por las repúblicas hispanoamericanas, tendrían que olvidar cualquier intervención del gobierno de la Gran Bretaña en beneficio de sus inversiones. Sin embargo, un análisis de las negociaciones bilaterales entre los acreedores, los diplomáticos británicos y los gobiernos de

13 Strange, en su artículo "Finance", 1994, sigue las ideas expresadas por Cain y Hopkins acerca del importante papel que desarrollaron los banqueros ingleses y la City, como los verdaderos promotores de la inversión británica en el extranjero. El corolario de estos intereses financieros fue lo que se ha conocido como el imperialismo inglés de finales del siglo xix. Los autores mencionados están inmersos en el debate para terminar con la clásica interpretación de los economistas marxistas acerca de la función esencial desarrollada por la burguesía industrial en el sistema capitalista y más particularmente en su última etapa que es el imperialismo.
México, demuestra que tal situación cambió progresivamente a consecuencia de la falta de pagos, de los préstamos forzosos y de la violencia en contra de súbditos británicos. Más aún, la protección del gobierno británico derivaba de un proceso de conversiones de la deuda mexicana y de convenciones diplomáticas cumplidas parcialmente, o que quedaron en suspenso. Siguiendo este razonamiento, los gobiernos de Gran Bretaña, Francia y España, intervinieron militarmente en México, argumentando las estipulaciones de la Convención de Londres (1861). Esta rápida negociación diplomática establecía que México debía cumplir con las convenciones referentes al servicio de la deuda, además de que era su obligación proteger la vida y la propiedad de los tenedores de bonos. Asimismo, las potencias estaban dispuestas a ayudar para el establecimiento de un gobierno legítimo, capaz y poderoso en México.

Algunos autores ingleses, especialmente aquellos hasta 1960, han repetido erróneamente que la protección de su majestad británica, en beneficio de los tenedores de bonos, fue por largo tiempo un asunto de dudosa índole. Subrayaban que la protección del gobierno británico se guiaba por los principios del derecho internacional aceptados como válidos en ese momento, además de que la especificidad de los casos había hecho necesaria la interpretación realizada por los oficiales del departamento jurídico del Ministerio de Relaciones Exteriores (Foreign Office). Siguiendo este criterio, la intervención en los asuntos mexicanos respondía a lo anterior, más que a 
presiones ejercidas desde la City. ${ }^{14}$ Sin embargo, historiadores contemporáneos han demostrado ampliamente que el apoyo del gobierno británico en cuestiones referentes a la suspensión de pagos de deudas soberanas, fue otorgada a los acreedores desde el principio del siglo XIX y continuó a lo largo de la centuria, inclusive durante el siglo XX.

George White, como otros hombres de negocios, políticos europeos, diplomáticos y gente diversa, quienes tenían algo que ver con la deuda de México, dio su punto de vista sobre el origen financiero de la intervención europea. Su análisis coincidía con la próxima ocupación de la ciudad de México por las tropas francesas (10 de junio de 1863). White le explicaba a Thomas Baring que la magnitud del servicio de la deuda había sido el resultado de varias concesiones hechas a los tenedores de bonos y de diversas promesas de pago, donde el gobierno mexicano hipotecaba importantes cantidades de ingresos vía impuestos de importación y exportación. Sin embargo, también reconocía que la opinión pública en los dos países consideraba que los préstamos a México se habían convertido en una parcela de especuladores, cuyas reclamaciones no debían ser apoyadas por el Ministerio de Relaciones Exteriores en Londres. Pero al mismo tiempo White preguntaba, ¿por qué los tenedores de bonos no pueden invocar la ayuda del gobierno británico, validando así el derecho de un acreedor a forzar a un país a pagar sus atrasos? El gobierno británico tie-

14 Turlington, Mexico, 1930, p. 14; Platt, Finance, 1968, pp. 72, 336. ne la obligación de proporcionar dicha ayuda, a menos de que se admita que un prestatario puede quedar libre del pago de sus deudas. ${ }^{15}$

Es un principio que se da por sentado, de que un gobierno deshonesto solamente tiene que perseverar en evadir el pago de

15 Las siguientes dos citas son consideradas como un excelente resumen descriptivo de los procedimientos desarrollados por el Foreign Office, por comerciantes británicos y por los gobiernos latinoamericanos en dificultades finacieras $y$ políticas. El análisis de Blow corresponde a la primera mitad del siglo XIX, en cambio, la descripción de Kennedy da cuenta del papel activo desarrollado por el gobierno británico y por los inversionistas en asuntos financieros y de comercio. Ambas descripciones con sus diferencias respaldan el amplio panorama de fuentes primarias y secundarias incluidas en este texto. Blow, British, 1972, p.142: "A few Secreraries for Foreign Affairs were keen and aggressive in fostering the commercial interests of their country. Through judicious use of entitlements and arguments, or pressure, even threats, they helped their merchants were not helpless for an officer of the Royal Navy might act as diplomat. Where governmental measures to win openings for Bricish goods failed, private individuals after resorted that the threat of it was used by diplomats to put pressure upon reluctant powers"; Kennedy, Realities, 1981, pp 60-61: "A cool detached view of politics, a global perspective, a distate for mere trade, for nouveaux rich and foreign governments which did not follow the gentlemany code[...] The bureaucratic structure of the Foreign Office $[\ldots]$ with rare exceptions they paid little attention to economic matters and claimed to have no interest in trade. Diplomacy should, if possible, be kept separate from business matcers, a prejudice only slowly abandoned under a barrage of press attacks upon the goverment's failure to protect and support British enterprise abroad in the face of unscrupulous foreign tactics." 
Cuadro 1. Préstamos de Estado y convenciones de la deuda mexicana otorgados al emperador Maximiliano

Concepto

Deuda Inglesa [Deuda de Londres]

Convención Diplomática Inglesa

Convención Española

Convención del Padre Morán

Convención Francesa Total

$\begin{array}{cc}\begin{array}{c}\text { Interés } \\ \text { (porcentaje) }\end{array} & \begin{array}{c}\text { Total } \\ \text { (dólares) }\end{array} \\ 3 & 51208250.00 \\ 6 & 4174280.00 \\ 3 & 6.623423 .11 \\ 6 & 825000.00 \\ & 199002.70 \\ & 63029955.81\end{array}$

FuENTE: White, "Foreign Debt of Mexico", en HC.4.5.36 [5]. En la década de 1860 el tipo de cambio entre un dólar estadunidense y un peso mexicano estaba a la par. Tradicionalmente la historiografía ha establecido que una libra esterlina era equivalente a cinco pesos, en este sentido el monto de los dólares considerado por White era equivalente a 12605991 libras. Otro dato importante es que la deuda francesa de México era aproximadamente $0.3 \%$ del total de la deuda internacional. Ninguno de los diplomáticos como George Mathew, Charles Wyke o agentes británicos como White reconocieron la validez del Préstamo Jecker por 15000000 de pesos. Esta situación cambió dos años después cuando oficiales franceses y banqueros se encargaron del servicio de la deuda mexicana.

sus deudas por un número suficiente de años para quedar liberado de sus obligaciones pecuniarias contraídas con extranjeros. O lo que es la misma cosa concerniente a México: quedar libre de toda obligación material o aprensión de pago. ${ }^{16}$

Los documentos elaborados por White acerca de la composición social de México, la identificación de sus problemas de corrupción administrativa, políticos y financieros han sido considerados como materia de análisis. Tales características señaladas por White son examinadas en este estudio como la última investigación semioficial británica en torno a la deuda externa de México. Las cifras manejadas en el cuadro 1 son previas a las cantidades que, como préstamos de Estado y conversiones de la deuda mexicana, fueron

16 White, "Mexican Sterling Debt", en HC. $4.5 .36[4]$. otorgadas al emperador Maximiliano, que no a México como país. Sus estimaciones fueron realizadas de acuerdo con fuentes oficiales del gobierno mexicano e información desarrollada por los anteriores agentes de los tenedores de bonos.

$\mathrm{Al}$ analizar las características de tales deudas, White afirmaba que la suma de la Convención Francesa estaba a punto de ser cubierta, debido a los fondos depositados en la Aduana de Veracruz, siendo ésta manejada por oficiales británicos desde enero de 1862. Es necesario resaltar que este procedimiento fue ideado por el ministro extraordinario Charles Wyke, de acuerdo a las instrucciones diplomáticas (1861) ordenadas por el secretario John Russell, que hacían énfasis en el pago puntual de la deuda mexicana.

El atraso por concepto de intereses de la deuda externa de México comprendía un lapso de nueve años y me- 


\section{Cuadro 2}

Concepto

Deuda Inglesa [Deuda de Londres]

Convención Diplomática Inglesa

Convención Española

Convención del Padre Morán

Convención Francesa

Total

Total: principal e intereses
Total (dólares)

14594351.25

469373.95

1719359.60

99000.00

sin datos disponibles

16882002.70

79912040.61

FUENTE: Véase cuadro 1.

dio hasta el primero de julio de 1863 (véase cuadro 2).

La suma total de la deuda externa de México por aproximadamente 80000000 de dólares era equivalente a 15982408 libras. Esta cantidad de dinero, hasta 1863 , había sido reconocida por los acreedores británicos, españoles y el gobierno de Juárez.

Es indispensable considerar que el monto anterior es sobresaliente, tomando en cuenta el trabajo realizado por E. Kozhevar quien, sin duda alguna, fue el autor decimonónico más preciso en el manejo de las cifras concernientes a la deuda mexicana. Debe apuntarse que en 1846 se estableció la totalidad de la deuda externa por 11204275 libras. ${ }^{17}$ Ello quiere decir que, en un periodo de 17 años, la deuda creció en 4778003 libras, lo que significa 1000000 de libras más que el total en efectivo recibido por México como resultado de los préstamos de 18241825 , confrontando el país un endeudamiento en bonos por $6400000 \mathrm{li}$ bras. Lo anterior es sin lugar a dudas un contraste importante, al revelar que

17 Kozhevar, Report, 1886, p. 47. entre 1846 y 1863 la deuda se había tornado impagable, y por tanto, en un asunto peligroso para la integridad de México.

Más aún y esencial para el argumento de este estudio, para 1863 las cantidades manejadas por George White revelan que la suma total de la deuda perteneciente a los acreedores británicos correspondía a 70 de los 80000000 de dólares del total de la deuda mexicana, equivalentes a cerca de $90 \%$. Indudablemente lo que se ha dado en llamar como la Deuda Inglesa era la deuda de México. El monto de las obligaciones británicas (Deuda de Londres y Convención Inglesa), las debatidas y por el momento no admitidas reclamaciones en contra de las administraciones mexicanas desde 1852 hasta el momento de la intervención, todas ellas produjeron poder político y financiero a los acreedores británicos de México y, al mismo tiempo, otorgaron autoridad a los diplomáticos ingleses, empeñados en negociaciones bilaterales que dieran por resultado un pronto y efectivo pago.

Finalmente, este artículo sostiene que la deuda de México por 79912040.61 
dólares, reconocida desde 1850-1851 hasta el gobierno de Juárez en 1863, debe compararse, primero, con los montos de los préstamos contratados en Londres y París a partir de 1864 por el emperador Maximiliano, y luego, por la diversidad de intereses creados a partir del establecimiento del imperio. Ambas cuestiones constituyen lo que se ha llamado como la Deuda Imperial. Es indispensable subrayar que los nuevos créditos cambiaron, por espacio de tres años, la relación de poder e influencia entre los banqueros que sostuvieron al Imperio de Maximiliano y a aquellos que podemos llamar como los históricos tenedores de bonos de la Deuda Inglesa. Los datos esenciales de los créditos de 18641867 serán analizados más adelante en el siguiente apartado.

La última sección del reporte de George White examina el importante asunto referido a las cantidades hipotecadas que debían ser cubiertas por las aduanas marítimas mexicanas. Su idea era la de proporcionar información adicional, creando una base útil que sirviera a diplomáticos y agentes británicos en las inminentes negociaciones bilaterales en torno a los montos y en la puntualidad de los pagos. Tales condiciones estarían estipuladas en futuras convenciones diplomáticas.

Su análisis estaba basado en el hecho de que desde el "Acuerdo unificador de la deuda", de 1830, los impuestos por concepto de importación y exportación se comprometieron en diferentes porcentajes, de acuerdo a la suma adeudada, al poder del acreedor (nacional o extranjero) y a la magnitud de los perjuicios como resultado de ac- ciones violentas en contra de la vida y las propiedades de europeos, estadunidenses y ciudadanos mexicanos que se amparaban en los ministros extranjeros. Este proceso de convenios no cumplidos sobre la deuda y al mismo tiempo daños a terceros, como consecuencia del continuo conflicto político, había terminado con la suspensión de pagos de la deuda ordenado por el gobierno juarista en julio de 1861. La anterior disposición había dañado irreversiblemente las relaciones entre los dos gobiernos y al mismo tiempo había terminado con la poca confianza que aún tenían los tenedores de bonos.

White sostenía que el total de los fondos hipotecados era de $59 \%$, correspondiente a los impuestos de importación en todas las aduanas marítimas del país, $10 \%$ extra, bajo el mismo rubro en los puertos de Tampico y Veracruz, $75 \%$ correspondiente a los impuestos de exportación en los puertos del litoral Pacífico y, finalmente, $5 \%$ también de exportación a ser aplicados en los puertos del Golfo de México.

Los porcentajes asignados en cada caso son ciertamente una carga pesada a los ingresos de México, pero menos onerosos de lo que aparentan a primera vista. Bajo las leyes vigentes todas las importaciones están sujetas a tarifas adicionales que hacen un agregado de $71 \%$. La tarifa establecida referente a los derechos de importación es de 59/171 y de 10/171, lo que significa cantidades menores a $35 \%$ y $6 \%$, respectivamente. Este sistema de tarifas agregadas es sin duda un fraude en contra de los acreedores de México[...] sin embargo, por otro lado, es una costumbre de los escritores mexi- 
canos que analizan las finanzas abogar pobreza[...] ellos no hacen referencia a estos cobros adicionales y otros recursos directos a los ingresos del país. ${ }^{18}$

Las quejas de White acerca de las tarifas adicionales es indudablemente una cuestión que no había sido mencionada por otros agentes y diplomáticos británicos. El cobro de dichos derechos extraordinarios tenía dos orígenes: préstamos forzosos que bajo el rubro de impuestos eran requeridos por las autoridades locales o modificaciones a las tarifas de importación y exportación, mismas que siempre fueron publicadas por la Gaceta Oficial del Gobierno Mexicano. A lo largo del siglo y particularmente en el tiempo analizado, existió entre los acreedores y el gobierno deudor una auténtica confrontación. Los primeros creían que sus derechos siempre habían sido infringidos; el último, apoyado por la prensa, consideraba a los tenedores de bonos como especuladores, como gente sin vínculos con los intereses y necesidades del país.

Los datos manejados por White como fondos previamente asignados e hipotecados eran similares a aquellos descritos por George Mathew, encargado de Negocios en mayo de 1861. Sin embargo, existía una diferencia entre ambos despachos, para Mathew el hecho de que la república tuviera semejantes cantidades de ingresos hipotecados era una cuestión de tiempo que el gobierno mexicano llegara a un estado de insolvencia. Contrariamente, el agente del banco Baring no con-

${ }^{18}$ White, "Foreign", en HC.4.5.36, s. p. sideraba dichos fondos hipotecados como un riesgo para el país. Debe recordarse que cada suspensión de pagos era para México una carga extra, resultado de la imposición de un porcentaje mayor en los ingresos aduanales destinado para el servicio de la deuda. ${ }^{19}$ Los estudios sobre el tema únicamente han considerado las tasas de interés y los fondos para el servicio. Sin embargo, debe considerarse que, desde 1830 hasta 1863 , el proceso de suspensiones, conversiones y el establecimiento de fondos para el servicio de la deuda resultó en una profusa y confusa legislación en torno al tema.

Más importante, los ingresos hipotecados y la imposibilidad de ser remitidos a los acreedores terminaron por dañar la soberanía e integridad de México. Lo último es sin duda una cuestión esencial. Como resultado de esta situación, el país se vio afectado de la siguiente manera: en 1837, los tenedores de bonos recibieron como garantía terrenos baldíos en California y Nuevo México. Una vez patentes los resultados de la guerra México-Estados Unidos, el gobierno británico presionó para que los acreedores recibieran como compensación una parte considerable de la indemnización estipulada en el Tratado de Guadalupe-Hidalgo. Después, en 1850-1851, los acreedores al consentir reducir en dos puntos los intereses anuales de la deuda de Londres, consiguieron asegurar un porcentaje de los ingresos aduanales de la costa pacífica. La guerra de Reforma alargó la suspensión de pagos trayendo como

19 Ortiz, Apuntes, 1886; Dougherty, "Gran Bretaña", 1964-1965; Bátiz , "Aspectos", 1983. 
consecuencia la firma de la Convención Dunlop y del Memorandum Aldham (1859-1860), que incrementaban considerablemente las cantidades asignadas en las aduanas marítimas. Finalmente, al tener enfrente la intervención europea, el gobierno de Juárez no solamente reconoció y aceptó en 1862 las propuestas de Charles Wyke, que establecieron los montos a ser recabados en las aduanas, sino que las autoridades de México aceptaron que hubiera un agente de los tenedores de bonos en cada una de las aduanas marítimas, dicho puesto sería ocupado por un vicecónsul honorario de la Gran Bretaña. Estos oficiales tenían poderes para recibir los montos y remitirlos a Londres, más aún, estaban facultados para solicitar asistencia militar de Inglaterra, en el caso de otra suspensión de pagos o que debido a un alzamiento militar fuera impuesto un préstamo forzoso. Las mencionadas características eran la esencia de la Convención de Puebla, documento cuyos términos significaban un atentado a la integridad y soberanía de México. Asimismo, era una intervención directa en los asuntos de administración financiera del país, procedimiento utilizado por las potencias durante el siglo XIX. El gobierno de Juárez aceptó dicho tratado como una manera de evitar el apoyo británico a la invasión francesa y al proyecto de establecer una monarquía en el país.

Hipotecar los derechos aduanales, los más importantes de la república, era la manera de pago exigida por los tenedores de bonos y reaciamente aceptada por las administraciones mexicanas. Esta práctica era en sí un pro- ceso que estaba en contra de los principios que hoy los economistas llaman crisis financiera. Las negociaciones para reanudar el pago de la deuda, entre 1830 y la década de los sesenta, fueron contrarias a la idea de buscar una solución que llevara a un verdadero, pronto y efectivo pago de las obligaciones mexicanas. Willian Wynne, quien analizó este problema, señaló las bases teóricas en que debía estar basada la renegociación de las deudas soberanas y definió la cuestión de la siguiente manera:

Un gobierno en incumplimiento de pagos es totalmente distinto a cualquier otro. El acreedor no puede obtener un dictamen favorable y exigir su cumplimiento sobre el gobierno deudor[...] el acreedor se ve en la necesidad de concertar y hacer todos los ajustes que le sean posibles[...] Las negociaciones son concebidas en el sentido de llegar a un resultado que tenga la manera de ser ajustado y que sea persistente. Asimismo éstas deberán comprender las necesidades del pais deudor, con la idea de restaurar su crédito dañado y principalmente, evitar que otra situación de suspensión de pagos pueda presentarse. 20

Charles White terminó su reporte sosteniendo que las dificultades financieras de México no eran atribuibles a la carga que significaban las deudas externas y a los convenios bilaterales, sino a la imprudencia y extravagancia del gasto gubernamental. Más aún, la respuesta podía encontrarse desde la

20 Wynne, "Foreign", 1933, p. 282 (has cursivas son mías). 
existencia de administraciones deshonestas, hasta en el perpetuo desperdicio de los recursos públicos, debido a los problemas políticos y "en mantener ejércitos inútiles para el beneficio de una horda de comandantes aventureros; lo mismo que una multitud de ineficaces empleados públicos". ${ }^{21}$

El documento varias veces citado es una mezcla de observaciones bien fundamentadas hechas por un empleado con tan solo unos meses en México, péro al mismo tiempo, y como resultado de lo anterior, prejuicios del momento caracterizado por una invasión extranjera y la salida del gobierno de Juárez de la ciudad de México rumbo a San Luis Potosí. Los juicios expuestos por White siguen algunos de los problemas identificados por Lucas Alamán, Mariano Otero, José Ma. Lafragua y Miguel Lerdo de Tejada, entre otros, quienes ya habían escrito acerca de los problemas resultantes de gobiernos deshonestos, la excesiva burocracia, el papel jugado por el ejército y sus comandantes, siempre dispuestos a participar en cualquier "revolución". Lo anterior era un modus vivendi y la manera para acceder a la presidencia de la república.

Tomando en cuenta lo ocurrido durante la guerra de Reforma y el año siguiente, tres asuntos sobresalientes determinaron la relación entre Gran Bretaña y México: las convenciones diplomáticas para solucionar el servicio de la Deuda Inglesa (1859-1860), la ley de julio de 1861 que suspendía por dos años el pago de la deuda interna y externa de México, y la Conven-

${ }^{21}$ White, "Foreign", en HC.4.5.36, s. p. ción de Londres (octubre de 1861) que estableció las bases de una situación cuyas consecuencias militares y financieras eran perceptibles en julio de 1863.

\section{Otras perspectivas}

Una vez en Inglaterra, Charles Wyke, conocedor de la problemática de América Latina, reconocido como una persona conocedora de los problemas financieros de México y que tenía la convicción de la necesidad de un pronto acuerdo entre los acreedores y el gobierno liberal, fue requerido por Thomas Baring para conocer su punto de vista acerca de los asuntos mexicanos dentro del ámbito internacional. Las cartas a Baring contienen muchos datos sobre la debilidad del partido conservador y la inexistencia en el país de tradiciones monárquicas. Al mismo, tiempo dan cuenta de las razones en torno a la desorganización del país, lo irregular de la administración financiera y los problemas políticos: asuntos ya descritos por él mismo al Foreign Office.

Wyke comunicó a Baring que tenía información fidedigna acerca de un proyecto francés para organizar un préstamo a favor de Maximiliano por 25000000 de francos. Asimismo le mencionaba que el archiduque tenía reputación de ser liberal en asuntos políticos. Ambas cuestiones podrían desarrollarle problemas en el futuro inmediato, tomando en cuenta la bancarrota de México y su incapacidad para hacer frente al servicio de la deuda. Más aún, porque aquellos que estaban promoviendo en Europa y en Mé- 
xico su candidatura (conservadores y monárquicos) querían que el príncipe revirtiera los efectos que en los bienes raíces había tenido el proceso, primero de desamortización y luego la nacionalización de bienes eclesiásticos, entre otros asuntos. Este tema era importante, pues muchos inversionistas ingleses se habían beneficiado de tales reformas. Por otro lado, Wyke evaluaba que sin una presencia diplomática $y$ militar británica, los oficiales nombrados por él para estar en las aduanas de Tampico y Veracruz, no tendrían el poder necesario para administrar y remitir a Londres los fondos hipotecados para el servicio de la deuda. Y preveía que muy pronto, oficiales franceses los reemplazarían presentándose una confrontación de intereses. ${ }^{22}$

Algunos días antes de que Baring recibiera los anteriores reportes, el archiduque Maximiliano le informó al emperador Napoleón III que los acreedores británicos de México, lo mismo que los comerciantes de aquella nación, estaban entusiasmados de que él pudiera establecer en el país un gobierno duradero, eficiente, promoviendo al mismo tiempo los principios liberales como la base del nuevo orden monárquico. ${ }^{23}$ Por las mismas fechas el secretario lord Russell le informaba a lord Lyons, ministro británico en Washington, que si las nuevas autoridades en México también resultaban incapaces y desconocían los reconoci-

22 Charles Wyke a Thomas Baring, Londres, 11 de septiembre de 1863, en HC.4.5.43.

${ }^{23}$ Maximiliano a Napoleón III, Miramar, 27 de agosto de 1863 en Tamayo, Benito Juárez, 1972, vol. 8, p. 165. dos tratados bilaterales, el gobierno continuaría buscando un régimen capaz de cumplir puntualmente con sus compromisos. ${ }^{24}$

Las últimas tres cartas citadas revelan que, durante la segunda mitad de 1863, los gobiernos europeos, así como los distintos intereses económicos, consideraban ya un hecho el establecimiento de otra administración.

El documento del archiduque exhibe una alianza con los intereses económicos británicos, situación que se hará efectiva unos meses más tarde, en 1864, y que será el soporte financiero para el establecimiento del imperio. Pero al mismo tiempo, Maximiliano mostraba desinformación acerca de los asuntos políticos de México, como la relación de poder entre los partidos liberal, conservador y la naturaleza de la guerra civil. En este último sentido, los despachos citados de Wyke y Russell muestran las profundas dudas acerca de lo idóneo de la ocupación francesa y de las aptitudes del nuevo gobierno para cumplir con los compromisos bilaterales. Es importante destacar que la misiva de Russell reproduce la política exterior británica referente a México: el gobierno de Palmerston solamente apoyará la existencia de un nuevo régimen, siempre y cuando éste asegure el cumplimiento de las convenciones bilaterales.

Tanto la administración de Juárez como la de Maximiliano (1859-1867) tuvieron que hacer frente a dichos principios reguladores de la política exterior de la Gran Bretaña. Ambos

${ }^{24}$ John Russell a Lyons, Londres, 21 de agosto de 1863 , en ibid., p. 50. 
regímenes, en diferentes momentos y en circunstancias extremas, solicitaron un abierto y explícito apoyo para derrotar al enemigo (primero los conservadores y luego los republicanos). Ninguno de los dos obtuvo tal respaldo.

\section{LA DEUDA IMPERIAL}

La intervención francesa y el Segundo Imperio resultaron en un proceso de enormes obligaciones financieras que dieron existencia al régimen de Maximiliano. Él, personalmente, respondió a dicho respaldo al imprimir nuevos bonos de la Deuda de Londres y de la Convención Inglesa. En este sentido, la llamada Deuda Imperial la constituyen cinco préstamos, de los cuales dos son reconversiones.

Por otro lado, con el establecimiento del Imperio de Maximiliano, importantes intereses económicos y financieros de Gran Bretaña y Francia comenzaron a desarrollar inversiones que continuaron más allá de la caída del archiduque.

$\mathrm{La}$ fundación de un gobierno legítimo y fuerte, el Segundo Imperio, fue visto en Europa como la ruta para desarrollar una poderosa relación bilateral con sobresalientes connotaciones políticas y económicas. Maximiliano entendió que las potencias europeas habían intervenido en México como resultado de los daños a los intereses de sus súbditos, perpetrados a lo largo de la guerra civil en nombre de las autoridades conservadora y liberal. El régimen imperial comenzó las negociaciones a partir de 1852 para establecer el origen y el monto de las distintas reclamaciones británicas no reconocidas por los gobiernos mexicanos. Las reclamaciones eran un asunto espinoso y, a lo largo de varias décadas, había sido materia de instrucciones diplomáticas desarrolladas por el Ministerio de Relaciones Exteriores en Londres.

Por otro lado, el gobierno republicano de Benito Juárez advirtió a los acreedores de México, a los nuevos inversionistas y a aquellos gobiernos que estaban apoyando a Maximiliano, acerca de la ilegalidad del imperio y, en consecuencia, de sus compromisos. Estas cuestiones han sido estudiadas desde el siglo XIX por historiadores mexicanos, europeos y de Estados Unidos, más aun, por banqueros y políticos cercanos desde aquel entonces a los gobiernos involucrados en la intervención. Sin embargo, el propósito de esta segunda sección radica en la comparación de los datos entre 1864 y 1867 , con aquellas cantidades que oficialmente eran manejadas antes de la intervención francesa y que fueron señaladas en el apartado anterior. Este artículo incluye más información referente al papel jugado por los banqueros británicos, que denota el importante apoyo financiero otorgado por éstos a la empresa imperial, más allá del meramente moral jugado por la Gran Bretaña, postura que ha sido la más socorrida por la historiografía de aquel país.

\section{Los intereses financieros y los préstamos}

Charles Jones ha sostenido que, desde la segunda mitad del siglo XIX hasta el final de la década de 1920, muchas compañías de la Gran Bretaña llevaron 
adelante inversiones financieras en América Latina. Pocas fueron exitosas, pero aquellas otras se contaron entre las más exitosas del área. ${ }^{25}$ En este sentido poderosos intereses bancarios como Baring, quien por largo tiempo había estado representando a los tenedores de bonos de la Deuda de Londres como a los de la Convención Inglesa, jugó un papel decisivo en el establecimiento de un gobierno monárquico en México. Thomas Baring convenció a ambas categorías de acreedores para apoyar el establecimiento de un imperio mexicano gobernado por un príncipe europeo.

Para llevar adelante este proyecto, y en el sentido de conseguir los préstamos necesarios para la instalación del archiduque Maximiliano, era necesario abrir la Bolsa de Londres, misma que desde 1830 había permanecido cerrada para los gobiernos mexicanos. Ello debido a las sucesivas suspensiones de pago. La propuesta al proyecto político-financiero, que estaba siendo desarrollado por la Francia de Napoleón III, con el apoyo del gobierno británico y de los banqueros de la misma nacionalidad, era que desde un principio, los tenedores de bonos recibieran un pronto y efectivo pago que contrapesara a las diversas suspensiones mexicanas. El respaldo de los acreedores era indispensable para flotar cualquier préstamo en las bolsas europeas. Como parte de esta ingeniería financiera, poderosos intereses financieros en París, como las casas Pereires, Fould y Oppenheim y en Londres la casa Baring $y$ Glyn Mills, también estaban formu-

$$
{ }^{25} \text { Jones, "Commercial”, 1977, p. } 47 .
$$

lando un tema sobresaliente: la creación de un banco nacional en México. ${ }^{26}$

Para preparar el préstamo que daría sustento al Imperio de Maximiliano, y del cual participarían los tenedores de bonos, Baring le confió a su socio más cercano en la City de Londres, la casa bancaria de Glyn Mills y Cia., promover en el medio financiero la idoneidad de dicha transacción. Este estudio sostiene que existían razones de peso para escoger este banco mercantil, en lugar de casas famosas como la Rothschild o Goldschmidt. El Banco Glyn no había participado durante la segunda década del siglo en los préstamos a las recientemente independizadas repúblicas hispanoamericanas, y tampoco había sido afectado por las frecuentes suspensiones de pagos de tales Estados. Por otro lado, el crédito a Maximiliano, que no a México como país, tenía por respuesta las siguientes razones. Entre $1860 \mathrm{y}$ 1866 el mercado presenció otro boom de préstamos a países extranjeros, fue la segunda mitad del siglo la que vio el afianzamiento del sistema de bancos internacionales en la Gran Bretaña y también de los llamados bancos imperiales que operaban en las "colonias blancas" como Canadá, Australia, o en países independientes sin un sistema bancario. Glyn Mills y Cia. estuvo asociado en la creación del Banco Otomano, teniendo este país la mayor deuda externa del mundo, de acuerdo con las cifras del Consejo de Tenedores de Bonos Extranjeros concebido en 1868. La casa británica participó con el Banco

26 Baster, International, 1935, pp. 142-143, y más recientemente Ludlow, "Disputa", 1988, pl). $775-780$. 


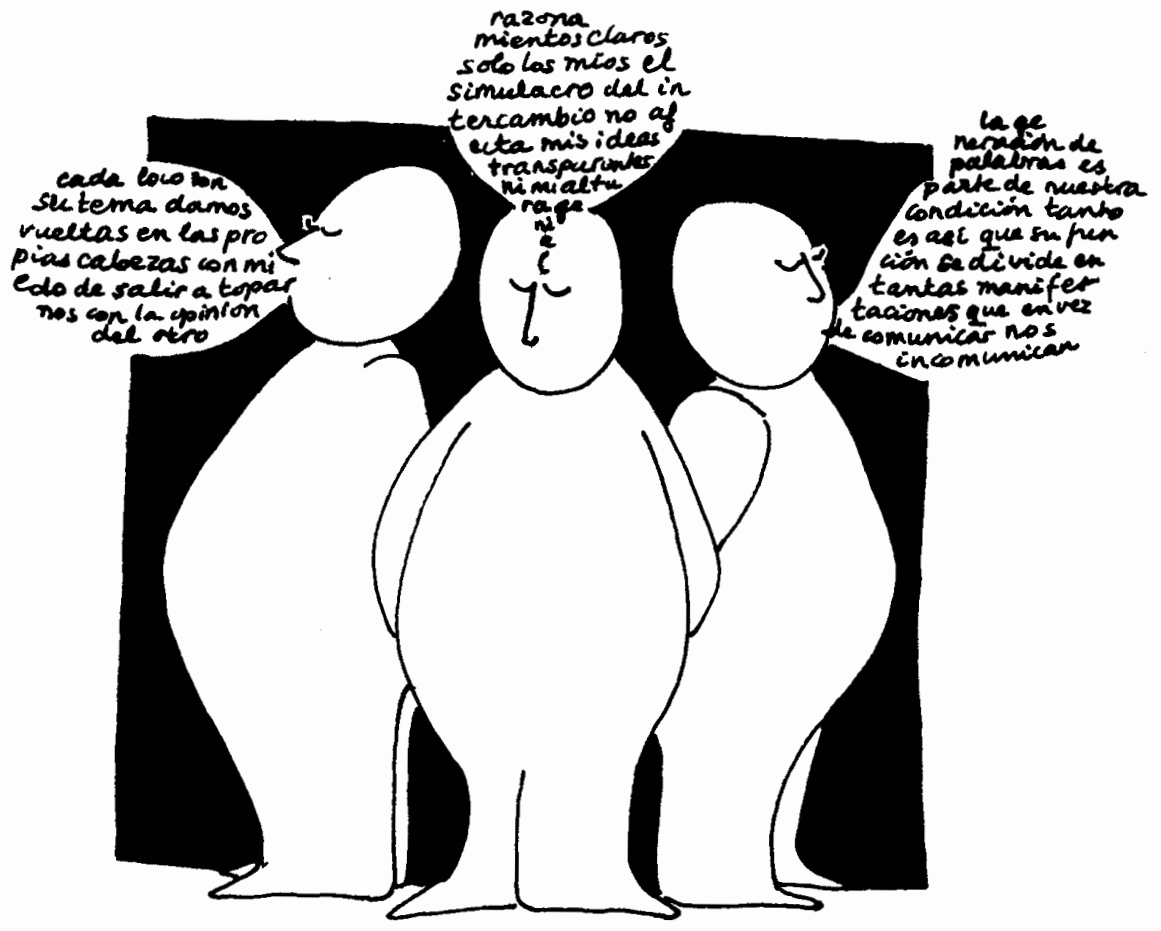


Brasileño y de Londres, después llamado el Banco de Londres y Sudamérica, una de las instituciones crediticias y de inversión más importante del área. El emperador de Brasil, don Pedro Braganza, pariente de la familia Habsburgo, garantizó la aprobación de la concesión. Siguiendo estas conexiones monárquico-finacieras, el gobierno reaccionario de Austria, que estaba en necesidad de un préstamo, se acercó a Thomas Baring. Éste canalizó la operación a George Grenfel Glyn, quien continuó con las negociaciones y el crédito fue otorgado. Como resultado de dichas negociaciones Glyn fundó el Banco Anglo-Austriaco el 4 de enero de 1864.

Sin lugar a dudas a través de la conexión con la familia Habsburgo, Glyn fue responsable de la flotación del préstamo mexicano en el mismo año, cuando el archiduque Maximiliano se convirtió en emperador de México. El préstamo fue recibido con ciertas reservas en Londres. ${ }^{27}$

Este artículo sostiene que no fue uno sino dos los créditos levantados por Glyn Mills y Cia., además de su participación en el Tratado de Miramar, en el año de 1864. Dichas transacciones respaldaron los derechos históricos de los tenedores de bonos de Londres y de aquellos de la Convención Inglesa. La anterior era una condición sine qua non para negociar en Europa cualquier préstamo dirigido a México. Después de 36 años y que los acreedores brindaban su apoyo, el país

27 Fulford, Glyn's, 1953, p. 161. estaba en condición de recibir nuevos créditos, y ello también había sido posible gracias a que Maximiliano respondía por tales transacciones. Glyn Mills, una respetable casa bancaria británica, estaba profundamente involucrada en la fundación de un imperio en México.

Después de los créditos otorgados por Goldschmidt y Barclay de 18241825, y el complicado proceso de suspensiones de pago, conversiones y la impresión de nuevos bonos de la deuda mexicana, ningún otro banco londinense había otorgado créditos a las autoridades del país. Los préstamos manejados por Glyn Mills, aunque no eran de un gran monto, fueron esenciales para el establecimiento del gobierno de Maximiliano. En este sentido, tales transacciones financieras fueron solamente posibles porque los gobiernos y los intereses financieros europeos involucrados en el proyecto monárquico, llegaron al convencimiento de que un cambio en el sistema político de México era el único camino que podría resultar en pagos puntuales y en la posibilidad de realizar prósperas inversiones. Maximiliano respondió a tal respaldo reconociendo el monto principal e intereses de la deuda externa de México. Finalmente, este trabajo sostiene que el papel de Glyn en México no terminó en 1864: en los años ochenta, Glyn se convirtió en el agente del gobierno mexicano y, al mismo tiempo, en la institución representante en Londres del Banco Nacional de México. Más aún, Glyn fue el encargado de remitir y hacer efectivos los pagos para saldar la deuda inglesa de México. Asimismo, este banco britá- 
nico participó en el financiamiento de tres líneas de trenes mexicanos. ${ }^{28}$

En París, el 8 de marzo de 1864, François Zichy, canciller de Francia; George E. Seymour, agente de Glyn Mills, y Joaquín Velázquez de León, enviado especial del archiduque Maximiliano, terminaron un contrato a favor del imperio mexicano. ${ }^{29}$ Desde el principio, el documento muestra asuntos interesantes. Tomando en cuenta que era un contrato privado entre un banco inglés y un príncipe austriaco - hasta el momento él todavía no era emperador de México-, el acuerdo estaba respaldado por el gobierno imperial de Francia en la persona de Zichy. Lo anterior representaba un apoyo directo de Napoleón III. En segundo lugar, el enviado mexicano había sido mencionado por Charles Wyke como un tenedor de bonos por la cantidad de

28 "George Carr Glyn (1797-1873) participó prominentemente en el desarrollo de los ferrocarriles en Inglaterra y en el extranjero. Era amigo de William Gladstone, quien siendo ministro de Hacienda, frecuentemente lo consultaba sobre asuntos financieros", Gore-Browne, History, 1933, p. 18 .

29 Joaquín Casasús en su libro Historia de la deuda inglesa fue el primero en mencionar que en 1864 un banco británico, Glyn Mills había otorgado un préstamo a Maximiliano. Posteriormente la literatura sobre el tema, en algunos trabajos, ha mencionado el monto y en otro la identidad del acreedor. Sin embargo, desde el siglo XIX hasta marzo de 1998, ésta es la primera vez que las estipulaciones de este contrato se analizan. Yo encontré y leí el documento en el Archivo Histórico del Royal Bank of Scotland. Alison Turton, jefa del archivo me dio permiso para fotocopiar este importante contrato pidiéndome que diera el crédito a favor de la mencionada casa bancaria.
27000 pesos. ${ }^{30} \mathrm{El}$ acuerdo crediticio estaba dividido en trece artículos que incluían las razones por las cuales se otorgaba el crédito, el monto, las condiciones y las sanciones que podrían suscitarse en caso de que el nuevo régimen fallara en reasumir el servicio de la deuda. ${ }^{31}$ El estilo del documento y la terminología fueron concebidos como un contrato privado entre Maximiliano y el acreedor. El texto hacía énfasis en el hecho de que el nuevo gobierno imperial estaba en la necesidad de recibir dinero contante a ser contratado en Francia y Gran Bretaña, ello para hacer frente a los problemas de la administración pública y al desarrollo de los servicios urgentes requeridos por el país. Más interesante aún, el contrato establecía que el emperador había comprendido que México requería de una completa y diferente organización política, aunado a una reforma en el orden financiero como administrativo. Este último párrafo iba más allá de las condiciones normales de un contrato de crédito; tal intromisión en asuntos de organización interna del país no estaba comprendida en los contratos con Goldschmidt o Barclay \& Cia.

Era sin duda alguna una intromisión y un atentado a la soberanía del país, pero las condiciones impuestas por los acreedores respondían a las ra-

30 Charles Wyke a John Russell, México, 26 de julio de 1861, en Foreign Ofice (en adelante Fo), 414.22.37.

31. Contrato entre el conde Franģois Zichy, George Edward Seymour y Joaquín Velázquez de León, reconocido por el emperador Maximiliano, 8 de marzo de 1864, en The Royal Bank of Scotland, Historical Archives, Londres, GM/399. 
zones resultantes de un proceso de suspensiones de pago que ya duraba más de 36 años. Estas condiciones de dudosa legitimidad fueron empleadas por los banqueros durante la segunda mitad del siglo XIX, y fueron aceptadas por monarcas y gobiernos en dificultades financieras. Más aún, tales prácticas pueden ser consideradas como un antecedente de los métodos hoy en día ampliamente desarrollados por el Banco Mundial y el Fondo Monetario Internacional.

La casa bancaria Glyn Mills estableció el tipo de cambio del presente crédito en 5.40 pesos mexicanos o 25.20 francos franceses por cada libra esterlina. Interesante dato, porque hasta hoy los especialistas interesados en las cuestiones financieras de México han continuado asentando el tipo de cambio de cinco pesos por libra, una diferencia considerable, tomando en cuenta las cantidades contratadas. El préstamo se llevó a cabo por la emisión de nuevos bonos de la deuda externa del país por un monto de 12000000 de francos (476 190.47 libras) a un interés anual de $6 \%$. El pago debía ser cubierto cada seis meses, el primero de abril y octubre en París y Londres. El contrato establecía que el archiduque Maximiliano reconocía estar comprometido con el gobierno francés en una convención diplomática por 66000000 (2 662363.85 libras) a 6\%. Además de convenir en que el gobierno mexicano en 1850-1851 había sido beneficiado por los acreedores, cuando éstos concedieron en reducir el interés anual de la deuda en dos puntos estableciéndolo a $3 \%$. Tal modificación se había hecho con la promesa de México de efectuar prontos y constantes pagos. El contrato Glyn establecía el reconocimiento de intereses no pagados por diez años, de enero de 1854 hasta enero de 1864, inclusive. La emisión de 20 nuevos cupones a 3\% debía cubrir el atraso por una década y tendrían que ser pagados puntualmente. El tratado estipulaba que el "gobierno imperial de México" tendría que pagar por adelantado 20333100 francos, equivalentes a 806869.04 libras, y con ello cubrir los atrasos por dos años. Esta cantidad debería ser depositada en la tesorería francesa en las siguientes fechas: julio 1864, enero y julio 1865 y enero 1866 . Se estipulaba que Glyn Mills y Cia. sería el encargado de realizar los pagos de los cupones en las fechas establecidas. ${ }^{32}$

En el contrato también se asentaba que el canciller de Francia, François

${ }^{32}$ Ibid. Es muy importante asentar que el contrato con Glyn Mills incluía una convención francesa por 66000000 de francos. Sin lugar a dudas era la respuesta a los bonos jecker, no reconcidos ni por el gobierno juarista ni por diplomáticos británicos, ni aun por agentes como George White. Por otro lado, el gobierno de Maximiliano cumplió parcialmente pagando las primeras tres parcialidades, pero fue incapaz de remitir el cuarto pago. En 1866 el Comité de Tenedores de Bonos Mexicanos no solamente ejerció presión en contra de las autoridades imperiales de México, sino que buscó la atención de Baring, advirtiéndole que otra suspensión de pagos sería desastrosa para el país. Miembros del Parlamento cercanos a Glyn Mills expusieron el problema durante las sesiones de este cuerpo. El Imperio Mexicano estaba quebrado porque, como otras administraciones mexicanas, la guerra en contra del gobierno republicano de Juárez había acabado con todos los fondos disponibles. 
Zichy, promovería en su país, como en la Gran Bretaña, una suscripción pública por 12000000 de francos (476 190.17 libras) a 6\% a favor del imperio mexicano; 40 nuevos cupones de la deuda imperial de México serían impresos en español, francés e inglés con la firma de un comisionado extraordinario. Además, serían estampados y garantizados por el emperador de México con su respectivo escudo de armas, y serían pagados dos veces al año. Finalmente la deuda contratada establecía los siguiente asuntos sobresalientes: a) Glyn Mills recibiría en co- misiones 3\% del valor nominal de los documentos manejados por sus corredores. Esta comisión terminaba cualquier pasado subsidio, intereses, cargo por emisión así como otras reducciones. b) En París sería creado el Consejo Financiero Mexicano, compuesto por un comisionado británico, uno de Francia y un delegado especial representando al gobierno de México. Esta institución estaría encargada de abrir una cuenta especial para la deuda del imperio mexicano y examinar cualquier asunto relacionado con la emisión de nuevos bonos, así como vigilar la puntualidad en el servicio de la deuda $y$ supervisar que el emperador realizara las reformas necesarias en la administración de México, con el fin de arreglar sus finanzas. ${ }^{33}$ Con la idea de res-

33 Ibid. Es necesario recordar que uno de los artículos más importantes de la ley del 17 de julio de 1861 era el establecimiento de un consejo regulador de la deuda mexicana, en el que estuviesen representados los acteedores de México tanto nacionales como extranjeros, oficiales diplomáticos y funcionarios mexicanos. La función paldar el presente crédito serían impresos nuevos cupones a $6 \%$ y, al mismo tiempo, se imprimirían nuevos títulos para reemplazar aquellos de la llamada Deuda de Londres de 1850 a 3 por ciento.

Un mes más tarde de haber reconocido el mencionado préstamo, Maximiliano, como emperador de México, obtuvo otro crédito de Glyn Mills por la suma de 8000000 de francos (317 460.31 libras); 3000000 serían recibidos por el príncipe austriaco y otros cinco cubrirían los gastos del ejército francés desde su desembarco en Veracruz hasta la fecha. ${ }^{34}$

Ambos documentos son muy importantes para los estudios de la historia mexicana referidos al proyecto de instalar a Maximiliano como emperador de México. Desde el siglo XIX, la literatura ha señalado que fueron mayoritariamente los intereses financieros franceses los que estuvieron invo-

de este cuerpo era estudiar los montos de la deuda y buscar la mejor manera de reasumir el pago puntual. La ley estableció como principio básico el reconocimiento de las diferentes deudas del país, exceptuando las reclamaciones sujecas a verificación. Más aún, el consejo, con la idea de obtener verdaderos resultados, fue facultado para tener un conocimiento realista de los datos económicos de México y especialmente que contara con información fidedigna sobre los ingresos y egresos de la república. En este sentido, el consejo instituido bajo las especificaciones del contrato Glyn Mills, aunque no era igual en sus propósitos, puede decirse que era similar al concebido por el gobierno de Juárez.

${ }^{34}$ Acuerdo entre Maximiliano, emperador de México y Glyn Mill \& Co., París, 10 de abril de 1864, en The Royal Bank of Scotland, Historical Archives, Londres, GM/339.62. 
lucrados, desde el Tratado de Miramar hasta Querétaro. Algunos investigadores han mencionado la existencia de un préstamo inglés y la minoría ha identificado a Glyn Mills, sin investigar las conexiones que en aquellos días tenía esta institución con otras casas bancarias y muy en particular las connotaciones políticas del apoyo financiero británico.

Una interesante excepción es el trabajo de Genevieve Gille. En su no muy conocido artículo acerca del papel jugado por los banqueros franceses durante el periodo de la intervención en México, ella sostiene que no solamente Baring y Glyn estaban interesados en el asunto. Contando con información directa desde México, la sucursal en París de Rothschild siguió de cerca las negociaciones $y$, en una primera instancia, consideró participar. Sin embargo, asuntos de dudosa solución pararon la inclusión de esta aristocrática y prestigiosa casa bancaria. Estos banqueros estaban preocupados acerca de los derechos de los originales acreedores (Deuda de Londres), más importante aún, ellos señalaron distintas reservas en torno a las garantías mexicanas que respaldaban dichos préstamos. James Rothschild hizo públicas sus dudas acerca de qué tanto tiempo el ejército francés estaría apoyando el establecimiento del nuevo imperio. Además, expresó su preocupación de si dicho régimen sería considerado mexicano o europeo. ¿Qué sucedería si la guerra civil continuaba en el país y nada de lo proyectado permaneciese? ¿Quién recolectaría los fondos de las aduanas mexicanas y quién los remitiría a Europa: oficiales británicos o franceses? Finalmente él entrevió una interesante cuestión, si la administración de Napoleón III continuaba apoyando en plenitud el proyecto imperial mexicano, Francia estaba adquiriendo una deuda peligrosamente importante, con un gran número de intereses y en diversos países de aquel continente. ${ }^{35}$

El banquero entendió que el mencionado apoyo para constituir un régimen monárquico en México no terminaba en los aspectos financieros de tales créditos. La empresa imperial respaldada por banqueros británicos y franceses era, como se ha dicho en principio, un contrato privado, pero que en su aplicación involucraba a gobiernos nacionales con intereses específicos y la realidad de un país en guerra.

Los expedientes de Glyn Mills ubicados en el Royal Bank of Scotland, la correspondencia diplomática del Foreign Office y los artículos publicados por la prensa decimonónica brindan suficiente evidencia para considerar lo complejo de la discusión. Se ha continuado señalando que en el caso específico del proyecto de Maximiliano, la administración de Palmerston estuvo fuera de las maniobras para instituir una monarquía en México. ${ }^{36}$ Sin embargo la realidad era otra, Glyn Mills, un renombrado banco británico estaba negociando un préstamo soberano con Maximiliano y en consecuencia con el gobierno de Napoleón III. Estas transacciones no fueron llevadas a cabo en secreto. La prensa y los intereses finan-

35 Gille, “Capitales”, 1998, pp. 125-151. 36 Turlington, México, 1930, pp. 168-173. 
cieros de la City en el Parlamento estuvieron discutiendo las preocupaciones y los beneficios de estar respaldando el establecimiento de un gobierno en México distinto al republicano.

Entre el gobierno de la Gran Bretaña y la City existía un real entendimiento. Inversionistas que estuvieran negociando importantes transacciones en distintos países buscaban la opinión del régimen, y el Ministerio de Relaciones Exteriores esperaba ser consultado, específicamente si las transacciones ponían en riesgo las políticas del gobierno británico en el extranjero. Sin lugar a dudas, el asunto sobre México era un tema sobresaliente, no solamente pensando en los derechos de los tenedores de bonos de Londres y de la Convención Inglesa, deuda calificada como insignificante en una sesión del Parlamento, sino considerando que la intervención estaba involucrando no solamente a Francia sino a las casas reinantes de Bélgica y Austria. Asimismo, el conflicto mexicano era un asunto importante para las administraciones de Jefferson Davis y Abraham Lincoln.

El gobierno de Palmerston no podía argumentar neutralidad y no estar involucrado en dichas transacciones financieras, porque además de ser conocidas públicamente, compromerían a la Gran Bretaña ante la comunidad internacional. Puede decirse que su gobierno no estaba completamente convencido acerca de lo idóneo del proyecto monárquico, pero no hizo nada para detener su realización. Cuando tres años más tarde era expresado que Gran Bretaña no le había hecho la guerra al régimen republicano, pudiera decirse que en 1864, Palmerston es- taba llevando a cabo la misma neutralidad, permitiendo a los agentes Confederados comprar armas y la construcción de navíos que fueron usados en contra de la marina de la Unión. Esta neutralidad británica constituyó lo que se conoce como las Reclamaciones Americanas. ${ }^{37}$ Edwin Borchard ha definido el problema del financiamiento y la neutralidad de la manera siguiente:

En tiempo de guerra, el derecho internacional impone ciertas obligaciones como el uso restrictivo de préstamos por parte de las naciones neutrales. Si bien es cierto que no hay reglas que obliguen a un neutral para que prevenga a un beligerante de recabar dinero por medio de préstamos otorgados por compañías de naciones neutrales, es una obligación del gobierno de dicho país neutral en prevenir que se hagan tales préstamos [...] Créditos a los beligerantes deben ser diferenciados de créditos a facciones o a insurgentes deseosos de promover un alzamiento en contra de un país amigo. Esto es una transacción ilegal y un rompimiento de las leyes sobre la neutralidad, que previenen sobre la posible no recuperación del crédito. Una cuestión difícil de establecer es cuando un gobierno insurgente es al mismo tiempo beligerante y reconocido como tal, o cuando es un gobierno de facto que controla el Estado. 38

37 Véase, Reclamaciones como resultado de la guerra civil americana, en Fo.5.1236-1333; Arbitraje a causa de la guerra civil americana, en Fo.5.1391-1426.

${ }^{38}$ Borchard, State, 1951, pp. 151-152. 
En suma, los dos préstamos de Glyn Mills y Cia. reconocieron los derechos de los tenedores de bonos, abrieron el crédito al emperador de México en las bolsas de Londres, París, y Amsterdam. El gobierno francés promovió dichas transacciones para establecer el régimen de Maximiliano y para recuperar montos importantes de gastos militares invertidos en la campaña desde 1862. El Segundo Imperio tomaba vida a partir de créditos personales. $\mathrm{Si}$ se comprenden las implicaciones de ambas transacciones financieras "toleradas" por la administración de Palmerston, puede decirse que un estado de guerra se constituyó entre el gobierno británico y la administración republicana de Juárez.

El Tratado de Miramar, del 10 de abril de 1864, es la tercera etapa en este proceso de deudas imperiales. El acuerdo fue firmado por el mismo Joaquín Velázquez de León y puede ser considerado como aquel que consolidó la existencia del Imperio de Maximiliano.

El Tratado de Miramar fue el acuerdo central del imperio. La suma contratada fue por 201000000 de francos equivalentes a 7976190.47 libras esterlinas. Para reunir el dinero fue encargado a la casa Crédit Mobilier, un banco con un número importante de inversionistas cercanos a la administración napoleónica. ${ }^{39}$ Después de al-

39 Walter Bagehot en su artículo "The Crédit Mobilier and banking companies in France" (1857) resaltó que Le Société Générale de Crédit Mobilier era considerada en toda Europa como una asociación establecida con propósitos siniestros y que representaba la peor especulación en la bolsa. La amplitud de los asuntos y la cantidad de gunas reducciones como el efectivo enviado a Maximiliano, la comisión otorgada a Glyn Mills por manejar los anteriores contratos más otros descuentos, las finanzas de México sufrieron un déficit de 294841.86 libras. Este préstamo incluía la emisión de nuevos bonos de la Deuda de Londres y de la deuda convencionada con Francia, España e Inglaterra, capital e intereses hasta 1864 por la suma de 83711511

dinero promovida por esta institución podía ser peligrosa para el capital internacional. Véase $\mathrm{Ba}$ gehot, Collected, 1978. Por otro lado, el vizconde Goschen expresó lo siguiente: Un célebre banquero francés, el señor Pereire ha llevado adelante algunas doctrinas económicas con la idea de establecer un máximo de ganancia y la posibilidad de establecer un banco nacional. Parece que el señor Pereire no solamente fue el fundador del inmenso Crédit Mobilier de Francia, negociador de enormes préstamos al extranjero, sino al mismo tiempo ha sido profesor de algunas muy atractivas teorías sansimonianas que pueden calificarse de alguna manera como filantropía utópica. Véase Goschen, Essays, 1905, pp. 5-6. Ambas citas coinciden con que la fundación del Crédit Mobilier no fue una pequeña empresa. Este banco estaba concebido para ser una institución nacional, abierto al público en general, en lugar de ser una casa bancaria frecuentada por aristócratas en desgracia y comerciantes. Los propósitos sansimonianos seguidos por el banquero coincidían con los aspectos liberales del régimen napoleónico. Pereire era un banquero judío de una familia portuguesa, igualmente que Oppenheim, el socio de Fould, quien fuera el encargado de negociar el empréstito de 1865 a Maximiliano. La conexión franco-judía en asuntos bancarios siguió a la caída del imperio. En los años ochenta Edmund Noetzlin, un banquero franco-suizo-judío, cooperó en el establecimiento de el Banco Nacional Mexicano y posteriormente participó en las negociaciones para poner fin a la suspensión de pagos de la deuda inglesa. 
pesos mexicanos, cantidad que equivalía a 16746302.20 libras. 40

$\mathrm{La}$ anterior era una suma cercana (80 000000 de pesos) a la concebida por George White en 1863 y que conocía Thomas Baring. Es interesante señalar que el presente tratado no incluía el importante monto de gastos de Guerra hasta 1864 y tampoco hacía mención como una deuda convencionada francesa, el asunto de los fraudulentos bonos Jecker por 15000000 de pesos (poco menos de 5000000 de libras).

Una vez que el acuerdo fue conocido por el público, Jesús Escobar, agente del gobierno de Juárez en Londres, publicó una carta en los periódicos el Daily News, The Financier y The Standard protestando en contra de las condiciones establecidas en el Tratado de Miramar. Escobar consideraba que el tratado convertía los bonos de 1850 y 1851 , identificados en este artículo como el Acuerdo Herrera y la Convención Doyle, en nuevos bonos con $40 \%$ de descuento. Señalaba que con este tratado, el llamado emperador aseguraba recibir dinero en efectivo a cambio de la promesa de tres pagos puntuales al año (dos de acuerdo al contrato Glyn Mills). Por otro lado, el agente republicano insistía que ni Maximiliano ni otra autoproclamada autoridad o régimen político, tenía la facultad, conferida únicamente por el Congreso, para establecer distintas condiciones a los tratados ya reconocidos o aceptar nuevos préstamos en favor de México. Continuando con su razonamiento sostenía un hecho cono-

40 Bulnes, Deuda, 1990. cido por el gobierno británico: los regímenes mexicanos y el actual gobierno constitucional de la república habían considerado la Deuda Inglesa como un asunto primordial y, desde 1862, la totalidad de ésta ha sido completamente reconocida. La deuda británica existía y además era completamente legal. ${ }^{41}$

Para finalizar, el agente Escobar, conocedor de la postura del gabinete juarista, del lenguaje y de los procedimientos legalistas de aquéllos, comprendió y trató de advertir a los acreedores ingleses que su apoyo a la fundación del Imperio de Maximiliano significaba desconocer los acuerdos existentes con los anteriores gobiernos republicanos.

Posiblemente, los acreedores le hubieran respondido que las autoridades mexicanas en más de una ocasión habían fallado en cumplir, primero, contratos privados con los banqueros ingleses y tenedores de bonos. Segundo, que los gobiernos republicanos habían sido incapaces de observar aquellas convenciones diplomáticas con el gobierno británico. México estaba enfrentando el resultado de errores de larga duración, del desorden en la administración pública y de los agravios cometidos durante la última guerra civil. Todo ello había acabado con la prosperidad del país.

El documento de Escobar fue uno de los últimos intentos para evitar que el gobierno británico y los tenedores

41 "Jesús Escobar, agente del gobierno constitucional de México al público interesado", Londres, 10 de junio de 1864 en Tamayo, Benito Juárez, 1972 , t. vill, p. 804 . 
de bonos se unieran al establecimiento del Segundo Imperio. El acuerdo firmado en el castillo de Miramar produjo dos categorías de acreedores británicos: aquellos que no convirtieron los llamados Bonos Herrera de 1850 y aquellos otros que compraron lo que podemos llamar como Bonos Miramar, de 1864. Esta cuestión no ha sido totalmente identificada por los especialistas en la deuda imperial mexicana.

Para entender por qué la intervención francesa y la fundación del Imperio de Maximiliano tuvieron poderosas connotaciones financieras, es necesario, aunque sea brevemente, examinar cómo fue establecido el primer banco moderno en México, una empresa que de ninguna manera es coincidente con los asuntos político-financieros de 1864.

La literatura que ha analizado lo que se ha dado en llamar como "bancos imperiales" incluye en esta categoría a instituciones que, teniendo sus oficinas principales en Londres, se establecieron principalmente en aquellos países no pertenecientes al imperio británico. Entre ellos, Estados como los de Latinoamérica, para quienes la libra esterlina era la moneda de uso corriente en las transacciones comerciales. Más aún, la libra se usaba en el manejo de inversiones a largo plazo, independientemente de si eran hechas o no con acreedores británicos. ${ }^{42}$ Es en esta categoría en la que se considera la institución que se estableció en México. No como un experimento aislado, sino como parte de una estructurada táctica financiera de alcances mundiales.

42 Presnell et al., Guide, 1985, pp. XIX-XX.
Un interesante miembro del grupo latinoamericano era el Banco de Londres, México y Sudamérica[...] Los directores del Banco Oriental y del Banco Provincial eran los promotores de la empresa mexicana con John Paterson, el famoso fundador del Banco Standard de Sudáfrica. ${ }^{43}$

En enero, un grupo de inversionistas ingleses obtuvieron del general Juan N. Almonte, jefe de la regencia en la ciudad de México, permiso para establecer un banco en el país. William Newbold era el director y Robert Geddes el cajero principal. Los dos banqueros estaban encargados de crear y organizar el nuevo banco. Ambos llegaron a México en mayo de 1864 , días antes de que Maximiliano desembarcara en Veracruz. Dos meses después, Newbold comunicó al gobierno imperial la apertura del Banco de Londres y México. Publicaron en los principales periódicos que la institución iniciaría operaciones con un capital por 2000000 de libras, equivalentes a un poco menos de 10000000 de pesos; ${ }^{44}$ 40000 acciones de a 50 libras cada una fueron inmediatamente compradas, y los agentes del banco demostraron que conocían los procedimientos mercantiles mexicanos. Además de que estaban bien informados acerca de la existencia de las más importantes casas de comercio en el país. Muchas de ellas pertenecientes a súbditos británicos, o bien, de mexicanos con una larga rela-

43 Baster, International, 1935, p. 141.

44 En 1867 la matriz en Londres tenía un capital de más de 5000000 de libras esterlinas, en Manero, Revolución, 1957, p. 8. 
ción comercial con los mercaderes exportadores de la Gran Bretaña.

El banco no paró en allegarse importantes ahorradores, sino que desarrolló una política de promover nuevos y pequeños clientes. Tiempo después el Banco de Londres y México tenía ocho sucursales en Veracruz, Tampico, Guanajuato, Zacatecas, San Luis Potosí, Morelia y Matamoros. Importantes ciudades comerciales, mineras y los tres puertos más importantes del Golfo. ${ }^{45} \mathrm{El}$ Banco de Londres fue la primera institución en México en introducir los cheques como moneda de uso corriente, y en febrero de 1865 introdujo los billetes: 1400 unidades con un valor de cinco pesos cada uno. Aunado a otras actividades, el banco, en conjunción con casas exportadoras en manos británicas, comercializó plata mexicana para ser exportada a Francia, China y la Gran Bretaña. 46

Este artículo coincide con el punto de vista de Walter McAleb en el sentido de que Newbold y Geddes fueron inteligentes en escapar de la inestabilidad política de las facciones mexicanas. El banco estuvo fuera de cualquier filiación partidista y mantuvo una respetable neutralidad. ${ }^{47}$ Cuando el Imperio de Maximiliano fue derrotado, el gobierno de Juárez revalidó la legítima existencia del Banco de Londres y México y, en el mismo año de 1867 . fue exceptuado de cooperar vía préstamos forzosos de las sumas requeridas por el ejército republicano para iniciar la administración de los servicios en la

\footnotetext{
45 Ludlow, “Disputa”, 1988, pp. 191-192.

46 Trueblood, 125 años, 1990 , p. 27.

47 McAleb, Present, 1920 , p. 40.
}

ciudad de México. ${ }^{48}$ Porfirio Díaz, que ocupó la plaza, y luego Benito Juárez como presidente de la república, estaban conscientes de las dificultades que otros préstamos forzosos pudieran resultar en nuevas reclamaciones británicas, argumento que tradicionalmente se ha utilizado para explicar una de las razones principales que resultaron en la intervención francesa.

Por otro lado, las administraciones republicanas tuvieron la suficiente sensibilidad para entender que los ciudadanos mexicanos, como los extranjeros radicados en el país, estaban usando los servicios del Banco de Londres y México para desarrollar tanto el comercio interior como el de exportación, ambos útiles para la vida económica del país. El banco fue importante para México y, por cerca de dos décadas, continuó como la única institución de crédito, sin considerar al Monte de Piedad.

Para los primeros meses de 1865 , la guerra de Intervención en México había incrementado sustancialmente el presupuesto del imperio. Los gastos personales de Maximiliano, sus ministros diplomáticos en el exterior y el servicio de la deuda establecido según los acuerdos con Glyn Mills y el de Miramar consumían todos los recursos.

18 Los súbditos británicos estaban protegidos de la exigencia de préstamos forzosos como resultado de las disposiciones del Tratado de Amistad, Comercio y Navegación de 1826. Este acuerdo no ha sido considerado por los especialistas como la base legal que respaldaba la existencia de la segunda deuda mexicana con Gran Bretaña, esto es la Convención Inglesa que era el resultado de las reclamaciones en contra del país. 
El imperio estaba quebrado. Teniendo este panorama, el ministro británico en México, Peter Campbell Scarlett, recibió del Foreign Office instrucciones para urgir al régimen imperial acerca de la necesidad de pagar puntualmente y de negociar un tratado acerca de las reclamaciones británicas no reconocidas desde 1852 a la fecha. ${ }^{49}$

Este artículo analizará la propuesta hecha por Scarlett, hasta el día de hoy no examinada en libros ya publicados, pero esencial para entender el proceso de endeudamiento masivo en que incurrió el imperio. Más aún, el plan de Scarlett de alguna manera seguía los anteriores análisis desarrollados por Doyle, Wyke, Mathew y White, quienes estudiaron la mejor solución para el servicio puntual de la deuda mexicana.

Scarlett juzgó la situación financiera mexicana como sigue. El imperio ha sido reconocido por las potencias europeas, pero necesita probar a aquellas naciones y al mismo México, una garantía sólida que satisfaga las estipulaciones de la Convención de Londres. El imperio debe tener una base firme para la ejecución de un plan económico que persiga lo siguiente:

La consolidación de toda la deuda en un solo fondo con un interés en común y algún tiempo (dos o tres años) para que pueda reorganizar su sistema financiero, porque esto el día de hoy es prácticamente imposible. Sí el emperador decla-

49 Peter C. Scarlett: secretario en Constantinopla en 1825, en París 1828; ministro en Brasil en 1834 , en Grecia en 1862 y en México en 1864, en The Foreign, 1865. rara una bancarrota la alternativa sería ceder parte del territorio mexicano, sin embargo, la sanción de ello constituye una violación a una de sus principales obligaciones que él mismo se impuso cuando aceptó la oferta del trono que le hicieron. 50

El documento, intitulado Project to the Formation and Working of a Mixed Commission ya revelaba, para 1865 , un desproporcionado aumento en la cantidad de dinero adeudado, considerando que para 1863 el total de la deuda mexicana era por 83000000 de pesos (principal e intereses según los reportes de George White) (véase cuadro 3).

El primer asunto que sobresale es la suma total de la deuda de México, sin el descuento propuesto hasta 1864 , por 226000000 de pesos, equivalentes a 41851830 libras esterlinas. El monto es gigantesco si se compara con las sumas totales que habían sido reconocidas por el gobierno de Juárez en 1863 , mismas que fueron manejadas por los diplomáticos británicos y los agentes bancarios. En un lapso de un año la deuda externa del país se incrementó en casi el $200 \%$, resultado ello de los préstamos señalados en esta sección y por el gasto de Guerra del ejército francés. Al analizar los datos de Scarlett, la deuda francesa (Guerra, Miramar y reclamaciones) sumaba 112000000 de pesos, 20000000 más que la deuda mexicana con Inglaterra, que había sido la deuda por excelencia desde 1824. Asimismo, lo sobresaliente de esta suma es que George White le había comuni-

50 Peter C. Scarlett a John Russell, México, 27 de febrero de 1865, en Fo.50.401.11. 
Cuadro 3. La actual deuda de México

\begin{tabular}{|c|c|c|c|}
\hline & $\begin{array}{l}\text { Monto } \\
\text { en pesos }\end{array}$ & & $\begin{array}{l}\text { Nueva cantidad } \\
\text { (reducción propuesta }\end{array}$ \\
\hline 3\% Deuda Inglesa & 75000000 & @ $50 \%$ & 37500000 \\
\hline $6 \%$ Convención Inglesa & 5000000 & $80 \%$ & 4000000 \\
\hline 3\% Convención Española & 7000000 & $50 \%$ & 3500000 \\
\hline 3\% Deuda Francesa (guerra) & 40000000 & par & 40000000 \\
\hline 6\% Tratado de Miramar & 60000000 & $70 \%$ & 42000000 \\
\hline Reclamaciones Francesas (Jecker) & 12000000 & par & \\
\hline Reclamaciones Inglesas & 12000000 & par & \\
\hline Reclamaciones Españolas & 10000000 & par & \\
\hline Reclamaciones Americanas/otras & 5000000 & & 39000000 \\
\hline Total & 226000000 & & 166000000 \\
\hline & Deuda nueva & & Intereses por año \\
\hline $\begin{array}{l}\text { Deuda Inglesa } \\
\text { (Londres, convencionada, } \\
\text { reclamaciones) }\end{array}$ & 53500000 & & 2140000 \\
\hline Deuda Francesa & & & \\
\hline (guerra, Miramar, reclamaciones) & 94000000 & & 3760000 \\
\hline $\begin{array}{l}\text { Deuda Española } \\
\text { (convencionada, reclamaciones) }\end{array}$ & 13500000 & & 540000 \\
\hline Deuda Americana/otras & 5000000 & & 200000 \\
\hline Total & 166000000 & @ 4\% & 6640000 \\
\hline Nueva deuda & 166000000 & @ $4 \%$ & 6640000 \\
\hline Créditos a favor de México & 20000000 & & \\
\hline Comisión de agencias & 4000000 & & \\
\hline Total de la deuda mexicana & 190000000 & intereses & 7600000 \\
\hline
\end{tabular}

Funente: Peter C. Scarlett, "Estimate to consolidate the debts of Mexico", México, 27 de febrero de 1865, en Fo.50.401.34. Las cursivas son mías y muestran lo exorbitante de la Deuda Francesa como resultado de la intervención.

cado a Thomas Baring que la deuda francesa de México era menos de $1 \%$ del total, y que para aquellas fechas (1863) estaría próxima a ser totalmente cubierta. Ello se debía a los fondos hipotecados por las convenciones y que eran remitidos a Francia por los agentes británicos que habían sido situados en las aduanas mexicanas por el ministro Charles Wyke.
Peter Scarlett entendió perfectamente que tal deuda por 226000000 de pesos era imposible de ser cubierta por México. En este sentido, la idea central de su proyecto era que los acreedores aceptaran hacer importantes reducciones. La propuesta de Scarlett estableció el total de la deuda de México en 190000 000. De acuerdo con los números expuestos, el ministro británico 
concebía una reducción significativa de $15.92 \%$. La tabla muestra que la mayor disminución sería hecha por los tenedores de bonos de Londres, en el lado contrario ninguna reducción en capital sería hecha por el gobierno francés, esto es, la deuda como resultado de propósitos militares. Lo mismo sucedería con las reclamaciones extranjeras. ${ }^{51}$ Scarlett incluyó este monto, a pesar de que muchas reclamaciones eran fraudulentas y necesitaban ser examinadas. En este sentido los quejosos estaban recibiendo un beneficio extra.

Otro punto importante del plan de Scarlett era unificar toda la deuda en un $4 \%$ de interés anual con todos los acreedores. Para algunas deudas significaba una reducción, para otras un logro. La unificación del interés anual estaba concebida como un buen procedimiento administrativo para aquellos agentes encargados de administrar y remitir los pagos mexicanos. El asunto llamado "Créditos a favor de México y la comisión de las agencias" por 24000000 de pesos no incluidos en el Tratado de Miramar, era una suma cercana al monto de las reclamaciones británicas, francesas, españolas y americanas, indudablemente una suma importante de dinero. Finalmente, para 1865, Scarlett computaba un total de intereses anuales por 7600000 pesos. En términos generales es importante

\footnotetext{
${ }^{51}$ Las reclamaciones británicas fueron examinadas por Scarlett y por aquellos funcionarios que representaban al gobierno de Maximiliano. El examen duró entre 1866 y 1867 . Sin embargo, "la disposición final de las reclamaciones no llegó a término sino hasta 1865", Tischendorf, "Anglo", 1957 , p. 479.
}

recalcar que las reducciones concebidas en la propuesta y el porcentaje de interés común a todas las deudas facilitaba el manejo de los recursos para el servicio de la deuda. Era una solución financiera que seguía los principios centrales de un acuerdo tendiente a evitar otra suspensión de pagos que pudiera dañar tanto al acreedor como al crédito del país deudor.

Cerca de un siglo después, en 1963 , la Secretaría de Hacienda publicó diversos documentos relativos a la "vieja deuda inglesa" que se había terminado de pagar en aquel año. De acuerdo con la publicación se demostraba que el tesoro del Segundo Imperio nunca tuvo más de 5000000 de pesos en efectivo por año. ${ }^{52}$ En este sentido, para aquel gobierno era imposible cumplir con sus compromisos financieros, mismos que fueron concebidos como respaldo de su existencia física y para el pago puntual en el servicio de la deuda externa de México.

Las autoridades británicas consideraron con razón, que la propuesta de Scarlett no incorporaba ninguna estipulación de cómo México podría pagar 190000000 de pesos más intereses. Por ello argumentaron que debía incluirse un artículo extra para corregir tal deficiencia. Este problema estaba resuelto en el proyecto de Charles Wyke conocido como la Convención de Puebla, que en 1862 había sido rechazada por Palmerston y Russell, ya que ambos estaban convencidos de que México necesitaba otro gobierno en quien confiar y no querían tener otra conven-

52 Secretaría de Hacienda y Crédito Público, Vieja, 1963, p. 23. 
ción con Juárez. ${ }^{53}$ Londres contestó que el plan de Scarlett, el cual ofrecía un periodo de gracia de dos o tres años para reiniciar el servicio de la deuda no era aceptable. Esta negativa respondía al origen de la ruptura diplomática británica a raíz de la Ley de Suspensión de Pagos decretada por el gobierno mexicano en julio de 1861. En tal disposición se estipulaba que la suspensión sería tan sólo por un periodo de dos años, por tanto, John Russell consideró que negar la propuesta de Scarlett era un asunto de congruencia con la postura británica de aquel entonces y respecto a lo expresado por la ley mexicana de 1861 .

El esquema del ministro Scarlett recibió también los comentarios de Thomas Baring. La banca que representaba a los tenedores de bonos consideró interesante la idea de instituir un fondo único de la deuda con un común $4 \%$ de interés anual. Sin embargo Baring criticó los montos de las reclamaciones de todos los países en contra del gobierno mexicano que sumaban un total de 39000000 de pesos, o sea, $17.3 \%$ del total de la deuda. Final-

${ }^{53} \mathrm{La}$ Convención de Puebla estipulaba que el gobierno de Juárez recibiría de Estados Unidos un préstamo para cubrir los intereses no pagados a los acreedores de Francia, España y Gran Bretaña. Como garantía, el gobierno se comprometía en hipotecar las tierras baldías de la república. Por otro lado, Wyke obtuvo que los oficiales británicos estuviesen en la administración de las aduanas marítimas de México y además, que en caso de otra suspensión o desvío de los fondos pertenecientes a los acreedores, los oficiales contaran con facultades para solicitar el apoyo de la marina de su majestad británica. mente, teniendo una larga experiencia en los asuntos mexicanos, Baring argumentó que pese a la existencia de una administración honesta y eficaz en las aduanas, el país sería incapaz de pagar las sumas adeudadas y reconocidas por el emperador Maximiliano. ${ }^{54}$

Las cantidades manejadas por Scarlett, en febrero de 1865 , de pronto estuvieron fuera de uso cuando el $\mathrm{mi}$ nistro de Maximiliano en París, José Hidalgo, y las casas bancarias francesas de Fould-Oppenhein, Hottinguer y Pinard firmaron en abril un nuevo préstamo por 250000000 de francos franceses, equivalentes a 9920634.92 libras al $6 \%$ anual. ${ }^{55}$ Los bonos fueron vendidos con un $32 \%$ de descuento; el valor real de la operación fue de 6746031.74 libras, perdiendo México casi una tercera parte del monto total. Al descontarse las distintas comisiones, bonos de la lotería e intereses no pagados por un año de la deuda de Miramar, finalmente, el tesoro imperial de México recibió 3838284.44 libras en efectivo. Solamente un tercio del total de esta cuarta deuda contratada. Si estos datos revelan condiciones fraudulentas y que los acreedores

54 Thomas Baring a John Russell, Londres, 18 de abril de 1865, en Fo.50.401.8.

ss Achille Fould de Fould-Oppenheim era amigo personal de Napoleón III y consejero en asuntos financieros. Él tenía poderesos intereses con el duque de Morny. Fould fue ministro de Finanzas entre 1861-1867, y "cuando fue obligado en 1867 a entregar el puesto, él se sintió profundamente resentido y rechazó cualquier puesto que le ofrecieron. Inclusive aquel de embajador en Londres", en Emden, Money, 1937, pp. 139140; Francisco Bulnes, Deuda, pp. 6-9. 
estaban evitando, como en tiempos pasados, el análisis de las necesidades de México para evitar una larga suspensión de pagos y posiblemente la bancarrota del Estado, la última suma se dividió entre quince cuentas para pagar diversas deudas. Dichos adeudos iban desde las rentas para la familia Iturbide, escogida como heredera al trono imperial, hasta montos para cubrir parte de los llamados Bonos Jecker por 3160000 libras. ${ }^{56}$ En este sentido, el gobierno de Maximiliano tuvo que confrontar los gastos administrativos diarios con tan solo 678284 libras, habiendo contratado una deuda por casi 10000000 de libras.

El tratado Cesar-Dano constituyó el quinto préstamo al imperio y fue secretamente firmado en la ciudad de

56 Al final de la guerra de Reforma (1860) Jecker le prestó al presidente Miguel Miramón 750000 pesos, reconociendo la administración conservadora una suma desproporcionada en bonos. El banquero suizo solicitó al año siguiente 15000000 de pesos. El gobierno liberal de Juárez se opuso a reconocer dicha deuda. Sin embargo, hay que señalar que como resultado del préstamo Fould de 1865, Jecker recibió al menos 2840754 pesos, lo que significa una suma $200 \%$ más elevada que el préstamo otorgado cinco años antes. Véase Wynne, "Foreign", 1933, p. 28. Los bonos Jecker como préstamos a corto plazo fueron caracterizados por Barbara Tenenbaum como una práctica usada por los agiotistas. Estos procedimientos habían sido criticados por los diplomáticos británicos y agentes de los tenedores de bonos, porque de este modo las administraciones mexicanas comprometían futuros ingresos por obtener prontas aunque pequeñas cantidades de dinero en efectivo. Guadalupe Nava, en su artículo "Origen", 1998, pp. 109-120, da una detallada explicación acerca del asunto Jecker.
México en septiembre de 1865 . Era un tratado que organizaba cinco años de gastos militares, algunos de ellos incluidos en los acuerdos con Glyn Mills \& Cia., agregando otras sumas como resultado de cinco años de resistencia republicana a lo largo del país. Los montos manejados en este acuerdo establecían que 1000 francos por año por cada soldado francés constituían, solamente en el año de 1864, 38000000 de francos franceses, equivalentes a 1506936 libras. Más preocupante para la existencia del mismo imperio y para los intereses de los acreedores británicos y franceses comprometidos en el establecimiento del Segundo Imperio, era que el tratado determinaba que gradualmente el ejército francés sería reducido a 28000 soldados en 1865 , 25000 en 1866 y 20000 en 1867 ; 8000 soldados formaban parte de la Legión Extranjera y permanecerían en México por al menos otros seis años. Finalmente, el tratado establecía que el imperio mexicano debía cubrir el monto por el transporte marítimo calculado en 15873 libras por viaje. Cinco cruces al año sumaban 79365 libras, monto este último completamente separado de otros gastos de Guerra. ${ }^{57}$

Las condiciones del Tratado CesarDano respondían no solamente a que el imperio experimentaba dificultades financieras, sino a que el panorama internacional había sufrido cambios profundos. La guerra de Secesión había terminado con una victoria de la Unión, y primero la administración de Lincoln y después la de Andrew Johnson

57 Bulnes, Deuda, 1990, pp. 9-10. 
directamente comenzaron a ejercer presión diplomática para que se efectuase un retiro inmediato de las fuerzas napoleónicas de México. En Europa, la colisión entre Francia y Prusia era una cuestión de tiempo, y en este sentido el gobierno francés estaba en la necesidad de acumular recursos financieros y soldados. Finalmente puede decirse que, para 1865, los gabinetes europeos ya tenían profundas dudas acerca de que el Imperio de Maximiliano pudiese consolidarse.

\section{Las reclamaciones británicas}

El último asunto financiero, pero por ello mismo de tal importancia que este estudio quiere resaltar, es el tema de las no reconocidas reclamaciones británicas (1852-1867) en contra de regímenes mexicanos. Debemos recordar que a lo largo de este artículo se han diferenciado la Deuda de Londres y la Convención Inglesa, y en este apartado se integran las reclamaciones no incluidas en convención alguna. Las reclamaciones extranjeras habían sido durante la vida independiente de México un problema mayúsculo y tenían como base jurídica los artículos 8,10 y 12 del Tratado de Amistad, Comercio y Navegación firmado con Gran Bretaña en 1826. No importaba si los gobiernos habían sido federalistas o centralistas, liberales o conservadores, republicano o monárquico, cada uno tuvo que afrontar distintas demandas por parte de los representantes de Francia, España, Gran Bretaña y Estados Unidos como resultado de robos, confiscación de propiedad y préstamos forzosos. Casi la totalidad de las reclamaciones tenían por origen los daños inherentes a los alzamientos militares y posteriormente a la violencia generada por la guerra de Reforma. Durante este tiempo de inestabilidad política, los préstamos forzosos constituyeron la raíz de muchas reclamaciones. Estos préstamos eran el resultado de la autonomía con que se manejaban los gobernadores de los estados y las autoridades locales, lo anterior reflejaba la carencia de control por parte de los regímenes establecidos en la ciudad de México. Desde 1840, diplomáticos británicos y oficiales navales presionaron y obtuvieron el reconocimiento de ciertas reclamaciones, transformando un asunto que debía ser juzgado en cortes locales en una cuestión regulada por convenciones diplomáticas, comprometiendo a los gobiernos de Gran Bretaña y México.

El establecimiento del imperio, el proceso de los nuevos créditos y la conversión de la deudas anteriores reconocidas por el emperador Maximiliano evitaron que por más de dos años hubiera un análisis específico de las reclamaciones británicas. El ministro Scarlett comenzó un proceso de negociaciones de sumo complicadas, no solamente teniendo en cuenta que algunas demandas eran fraudulentas, sino tomando en consideración que el gobierno imperial mexicano quería que el procedimiento para examinar las reclamaciones se hiciera de acuerdo con leyes mexicanas. La oposición de la Gran Bretaña radicaba en que tal sistema legal era en extremo complicado, en cambio Londres recomendaba el uso del derecho internacional aceptado como 
válido en el momento de las negociaciones. El Foreign Office consideraba esta condición como la mejor garantía para cimentar las discusiones y llegar a una sentencia final.

Después de siete meses de amargas sesiones, Scarlett informó a lord Clarendon, secretario del ramo del gobierno conservador de Benjamin Disraeli, que al fin se había creado la Comisión mixta para el arreglo de las reclamaciones británicas en contra de México. Tres comisionados mexicanos representaban al imperio, el más importante era Tomás Murphy, consejero con facultades para concluir un tratado con Gran Bretaña. Este país estaba representado por Scarlett, por Frederick Glennie, cónsul británico en la ciudad de México y por Henry Gibbon. ${ }^{58}$ Ambas naciones reconocieron la necesidad de un árbitro y decidieron que el embajador español, el marqués de Rivera, era una buena opción. Este punto del documento es interesante porque España estaba esperando a que Gran Bretaña y Francia pudieran obtener una convención favorable para sus reclamaciones. Se estableció que la comisión debería examinar todos los casos sin que esto excediera el lapso de un año; las deci-

58 Scarlett a Clarendon, México, 20 de marzo de 1866, en ro.50.401.21. Con la excepción del ministro Scarlett, los otros tres mencionados, esto es Gibbon, Glennie y el ciudadano mexicano Murphy, eran tenedores de bonos. Debemos recordar que Murphy, junto con José María Luis Mora, llegaron en 1847 a un acuerdo sobre la deuda con los acreedores británicos. La única suma de dinero considerada en 1850-1851 y reconocida por ambos gobiernos después de la caída del Imperio de Maximiliano. siones de la misma serían terminantes. Se señalaba que el gobierno imperial de México se constituía en sí mismo como responsable de los montos a ser cubiertos en beneficio de los reclamantes. La comisión debía especificar las garantías de las formas de pago y de llevar una minuta detallada de sus sesiones y procedimientos. ${ }^{59} \mathrm{La}$ Comisión Mixta tuvo 24 sesiones y trabajó de agosto 10 de 1866 a mayo 6 de 1867.60

En algunos casos problemáticos, el árbitro español apoyó las reclamaciones británicas, específicamente cuando era confirmado que los gobiernos mexicanos injustificablemente habían creado o modificado la tarifa de los impuestos de exportación e importación. Al mismo tiempo, Rivera rechazó otros casos. El comisionado británico criticó a su parte mexicana de seguir tácticas dilatorias. Estos últimos consideraron que el embajador español sólo estaba defendiendo los intereses europeos. Tales problemas, la posible abdicación del emperador y, finalmente, la crisis militar que resultó en el viaje de Maximiliano a Querétaro, terminaron con las sesiones de la comisión. Es interesante señalar que durante la segunda mitad de 1866 y a lo largo de 1867 los reportes de Scarlett al Foreign Office no contienen información alguna acerca del progresivo deterioro económico, político y militar del imperio. Parecía que los trabajos de la Comisión Mixta se estaban

59 Ibid.

60 Book of minutes of the sittings of the Mixed Comission for the Settlement of British Claims against Mexico, en Fo.50.413.17. 

desarrollando en un país pacífico. El objetivo de los diplomáticos ingleses era lograr una nueva convención diplomática que finiquitase el asunto de las reclamaciones y que fuera obligatorio para un nuevo régimen ante el evidente colapso del imperio.

En resumen, el proceso de reconocimiento de cinco diferentes deudas que van desde los contratos con Glyn Mills hasta el acuerdo Cesar-Dano, Maximiliano reconoció una deuda externa por un total de 363369931 pesos, equivalentes a $72265081 \mathrm{li}$ bras. De acuerdo con los libros del imperio, tanto la Deuda de Londres como la Convención Inglesa daban un total de 83711511 pesos, equivalentes a 16742302 libras. ${ }^{61}$ Este estudio sostiene que, de acuerdo con tales datos, la deuda inglesa de México constituía tan sólo cerca de $22.88 \%$ de toda la deuda imperial para 1867. Ambas, la suma total de la deuda mexicana como el porcentaje referido a la británica, es un asunto sobresaliente si se compara con los datos manejados por Scarlett en febreto de 1865 , cuando la deuda inglesa constituía algo más de $40.7 \%$ del total. Lo anterior significa que en dos años la participación de los acreedores británicos disminuyó en un poco más de 18 puntos. Más aún, el propósito del artículo ha sido demostrar que la suma total por más de 300000000 de pesos debe ser comparada con el cálculo realizado por George White en 1863 , estableciendo la deuda inglesa de México por 70446254 pesos equivalentes a 13045602 libras; ello significa que la deuda inglesa antes del Segundo

${ }^{61}$ Payno, Cuentas, 1981, pp. 908-913.
Imperio constituía cerca del $86 \%$ del total de la deuda externa de México. En el lapso de cuatro años, el porcentaje de la deuda inglesa de México, que durante décadas había sido por excelencia la deuda del país, pasó de $86 \%$ a $22 \%$, una reducción en la participación que indica el nivel de endeudamiento reconocido por Maximiliano.

\section{La Doctrina Republicana}

La catástrofe de como terminó el Imperio de Maximiliano en México, sirvió para crear una permanente oposición en contra de proyectos en distantes y desconocidas tierras, sin una idea clara o una determinada política acerca de los objetivos a ser obtenidos.

Edmund Fitzmaurice, 1905

Los argumentos presentados en esta sección deben ser considerados no solamente como una respuesta a la deuda imperial contratada por Maximiliano, sino como la estrategia seguida por la administración juarista concebida a lo largo de la intervención y con el objetivo de que dicha aventura intervencionista no se repitiera nuevamente.

Este estudio quiere resaltar que los argumentos y las políticas llevadas a cabo por el gobierno británico, por los acreedores de México y por la administración de Juárez, fueron discutidas tomando como base la interpretación de los principios del derecho internacional. Los involucrados en el caso mexicano debatieron las razones y las consecuencias de la intervención francesa y el establecimiento del imperio, analizaron las condiciones establecidas en las convenciones diplomáticas, en los 
contratos financieros y en la interpretación que de estos acontecimientos era tipificada en los libros de derecho. Tomaron en cuenta los conceptos aceptados por los gobiernos occidentales. Más aún, se debatió el asunto sobresaliente que el gabinete juarista tomaba como punto de partida: la guerra de Intervención que terminó con los antiguos tratados y extinguió las relaciones diplomáticas entre las potencias europeas y México. Esta situación como un hecho dado determinó el statu quo entre el México republicano y la Gran Bretaña por 23 años.

\section{El papel de Jesús Terán}

Antes de que el ejército francés, a mediados de 1863 , ocupara la ciudad de México, el Congreso otorgó amplios poderes al presidente Juárez. Éste y sus ministros mudaron el gobierno a San Luis Potosí y de ahí a otras ciudades terminando en los confines de México, esto es el pueblo fronterizo de Paso del Norte. El viaje terminó al ocupar la ciudad capital cuatro años más tarde. Durante este tiempo, un grupo de estadistas cambió su visión sobre México, reforzó sus dudas concernientes a los gobiernos europeos y al mismo tiempo aumentó la desconfianza ya existente hacia Estados Unidos. Ellos desarrollaron una estrategia que iba desde los asuntos locales hasta políticas concebidas de acuerdo con el contexto internacional. La intervención francesa no era ni una guerra civil, ni un cuartelazo militar como los desarrollados a lo largo del siglo. La experiencia de la guerra de Reforma le demos- traba a Benito Juárez que un régimen no podía acabarse si se perdía una batalla o una ciudad. La soberanía del pueblo estaba en él, el asiento de los poderes radicaba donde él estaba y su administración no era como aquellas de Paredes, Canalizo y Comonfort que habían sucumbido porque no estaban convencidos de lo idóneo de sus objetivos. Juárez, Sebastián Lerdo, José Ma. Iglesias, Ignacio Mejía y otros como Matías Romero, Porfirio Díaz, Francisco Zarco y Jesús Terán, estaban convencidos de que la república al fin obtendría una victoria genuina. El país demandaba una severa reprimenda en contra de aquellos que habían apoyado el proyecto monárquico, este último asunto resultaba tomando en consideración el origen del conflicto y las atrocidades cometidas durante la intervención extranjera. El fusilamiento de Querétaro y los otros cometidos en contra de distintos jefes imperiales, las políticas relativas a la ruptura de relaciones diplomáticas y aquella otra referida a la no validez de las convenciones diplomáticas referidas a la deuda externa, todas estas medidas fueron concebidas como una auténtica represalia.

Este artículo pone la atención en el trabajo de Jesús Terán, enviado especial de Juárez en Europa y quien trató de obtener una entrevista con el secretario John Russell. No fue recibido pero le escribió tres cartas durante 1864 desarrollando el siguiente razonamiento. Gran Bretaña ha tenido como base de sus principios de política exterior el de reconocer a los gobiernos establecidos en las ciudades capitales. Inglaterra ha decidido que una vez que Maximiliano sea coronado emperador en la ciu- 
dad de México, reconocerá al régimen imperial. Si como resultado de tal acción el gobierno constitucional de México dejase de existir, nada se podría debatir, porque las potencias no tienen la obligación de examinar la legitimidad de los gobiernos en otros países. Sin embargo, el día de hoy, el gobierno constitucional de Benito Juárez continúa existiendo y sólo ha cambiado su residencia, utilizando las facultades extraordinarias con que está investido. En el día de boy existen en México dos gobiernos de facto. ${ }^{62}$

Terán añadió, Gran Bretaña no solamente ha mantenido relaciones diplomáticas con distintas administraciones mexicanas, sino que el actual régimen de México está comprometido con Inglaterra en acuerdos relativos a la deuda, mismos que reconocen los derechos de los acreedores (Convención Dunlop y Memorandum Aldham, 1859-1860). Más aún, su majestad británica, ignorando los acuerdos bilaterales y la legalidad de la administración de Juárez, ha decidido apoyar diplomáticamente al autoproclamado y de ninguna manera autónomo gobierno imperial de México. Estas dos últimas características -de acuerdo con los principios diplomáticos británicos- son por sí solas bases para evitar el reconocimiento. Como resultado de lo anterior y de acuerdo con los preceptos del derecho internacional, aquel imperio que es llamado como el nuevo régimen no debe ser respaldado, mientras continúe existiendo el legítimo

62 Jesús Terán a John Russell, Londres, 22 y 28 de julio y 6 de octubre de 1864 , en Tamayo, Benito Juárez, t. IX, pp. 267-268, 269, 437. gobierno constitucional de la república. Por otro lado, y en un intento por ganar el apoyo del secretario liberal John Russell, Terán subrayó que Inglaterra con tal actitud estaba apoyando a la facción reaccionaria y clerical en México, la cual por más de 40 años se había opuesto al establecimiento de los derechos civiles y a la libertad de credos. Esto último había sido una petición constante e importante de los diplomáticos británicos, misma que el gobierno liberal de Juárez había garantizado como resultado del establecimiento de las Leyes de Reforma.

Cambiando el objetivo de su razonamiento, continuó debatiendo los argumentos de la Convención de Londres y señaló una circunstancia que era preocupante para el gobierno de Palmerston: el cumplimiento de los acuerdos sobre la deuda. Terán apuntó la siguiente cuestión: cuáles eran las posibilidades de los tenedores de bonos de Londres y de la Convención Inglesa de ser pagados por el gobierno republicano y cuáles serían las probabilidades que ellos tendrían como resultado de la intervención francesa. Este dilema se planteaba porque el nuevo Imperio de Maximiliano se había inaugurado adquiriendo injustas y exorbitantes deudas que eran completamente desproporcionadas a los recursos del país. ${ }^{63}$

Don Jesús promovió en Londres, $\mathrm{Pa}$ rís, Madrid, Viena y Roma entrevistas con funcionarios diplomáticos, comandantes militares, directores de bancos y periodistas, exponiéndoles las razones de la resistencia republicana y de las dificultades que tendría que enfrentar

${ }^{63}$ Ibid. 
el archiduque. Terán fue en Europa lo que Romero desarrolló en Washington: promotor de un republicanismo intransigente $\mathrm{e}$ informador acucioso de lo que estaba pasando en el mundo y su conexión con la intervención francesa en México.

Seis meses después, Sebastián Lerdo de Tejada, ministro de Relaciones recibió del mismo Terán lo que este estudio reconoce como una de las más importantes cartas del tiempo de la intervención. El documento no ha recibido toda la atención de los especialistas, pero aquí se considera que tal manuscrito formula y provee de los argumentos necesarios en los temas de las relaciones diplomáticas entre el gobierno republicano y las potencias europeas, y de la interpretación jurídica sobre las bases en que estaban fundados los acuerdos bilaterales en torno al servicio de la deuda. Las relaciones diplomáticas y la deuda eran los dos asuntos que trataban lo que la historiografía ha llamado como la Doctrina Juárez o Republicana de 1867.

El razonamiento de Terán consideraba lo siguiente. En un periodo corto de tiempo (él estaba escribiendo en 1865) el gobierno republicano obtendrá una victoria decisiva en contra de Francia y, en consecuencia, un triunfo opuesto a los intereses de las potencias europeas que financiera y moralmente patrocinaron el Imperio de Maximiliano. Esta es la oportunidad, probablemente la única que tiene el país, para modificar los antiguos tratados con los gobiernos europeos, los cuales ban dañado el progreso y la integridad de la nación. Hoy esos regímenes han entendido que la guerra en contra de la república no ha sido una empresa fácil y se ha convertido en desgastante para sus tesoros. México debe estar seguro de que en el futuro las potencias sólo iniciarán una guerra considerando la defensa de muy poderosos intereses. Asimismo, la administración republicana debe proclamar internacionalmente que fueron aquellos países quienes desconocieron al gobierno nacional de México, cuando de acuerdo al derecho internacional, no tenían el derecho para proceder en tal manera. La táctica seguida por las potencias europeas le da al gobierno de México el derecho de terminar con todos los tratados. Más aún, a consecuencia del triunfo republicano, la administración debe abstenerse de toda relación que involucre a las potencias europeas y debe esperar a que sean los gobiernos de aquellas naciones quienes le soliciten el cumplimiento de los tratados bilaterales. La repuesta debe insistir en que cuando Gran Bretaña, Francia y España desconocieron, en 1861, al gobierno constitucional de México y promovieron una guerra en contra de la legítima autoridad del país, por esa sola acción, las potencias terminaron con todos los tratados y convenciones que tenían con México. La guerra trajo consigo una nueva situación, las relaciones diplomáticas y los tratados bilaterales podrán ser nuevamente establecidos, después de un proceso de negociaciones que establezca una distinta y equitativa relación entre México y las potencias europeas. ${ }^{64}$

Los conceptos expresados por Terán en 1865 no solamente eran su análisis del conflicto mexicano, sino su percep-

64 Jesús Terán a Sebastián Lerdo de Tejada, Florencia, 20 de abril de 1865, en ibid., t. X, p. 29. 
ción del escenario internacional y un examen jurídico de las consecuencias que la intervención militar había producido en los acuerdos bilaterales. Su interpretación del momento, como aquel estudiado por José María Iglesias, consideraba que la presente realidad estaba modificando el curso de la intervención europea en América. ${ }^{65}$ El gobierno de Napoleón III y el de la Gran . Bretaña estaban enfrentando la inminente victoria de los ejércitos de Abraham Lincoln. La cuestión que se hacía evidente era la de qué tanto poder tendría la Unión y cómo el gobierno federal de Estados Unidos podría presionar diplomáticamente en el asunto mexicano; más aún, qué tan rápido Francia podría cimentar el imperio como un gobierno legítimo y responsable. ${ }^{66}$

Aun cuando en la retórica diplomática y los debates en ambas casas del

65 Debe recordarse que la intervención francesa en México fue tan sólo un conflicto donde las potencias europeas se involucraron en los asuntos americanos. La guerra civil en Estados Unidos, la invasión a Santo Domingo, los bombardeos a puertos del Perú y Chile son acontecimientos que muestran que durante la década de los sesenta estaban en práctica las empresas intervencionistas que respondían al imperialismo que fue característico de la segunda mitad del siglo XIX.

${ }^{66}$ Case y Spencer, United, 1982, p. 577. Para entender el enfrentamiento entre ambos países, la siguiente carta de William Seward al marqués de Montolon muestra los asuntos que preocupaban a Estados Unidos: "El ejército francés ha invadido un país con el abierto deseo de reemplazar al gobierno nacional elegido por los mexicanos. Éste cuenta con muchas simpatías entre el pueblo estadunidense y sus instituciones. La monarquía apoyada por Francia es considerada por el gobierno de Estados Unidos como un insulto y una amenaza al sistema republicano establecido en
Congreso estadunidense se hablaba de solidaridad americana para con las autoridades mexicanas, era evidente que las potencias -Europa y Estados Unidos- no entrarían en guerra a favor de un pobre y débil país. El presidente Juárez argumentaba que las naciones poderosas a lo largo de la historia no han tenido amigos, sino solamente intereses que proteger. Aquellos Estados siempre han estado temerosos de ellos mismos y, considerando la realidad existente, a las repúblicas de Hispanoamérica no les quedaba otro camino que utilizar sus propios recursos. A los gobiernos de éstas les tocaba promover no solamente la emancipación y modernización de sus Estados, sino tenían la obligación de rechazar a los opresores de dentro y fuera. Finalmente Juárez declaró que México y su gente, que habían sufrido la violencia de una invasión extranjera, necesitaban de una victoria decisiva para que esta aventura no pudiera repetirse nuevamente. Él, quien ya había vivido en Estados Unidos, considerando la información oportuna de lo que sucedía en Washington y la percepción que sobre México tenía agregó: lo único que el país necesita es que el gobierno estadunidense nunca reconozca al régimen imperial de Maximiliano. ${ }^{67}$

América. Tomando en cuenta los verdaderos intereses y el honor de Francia, este país debe, en un periodo corto de tiempo, encontrar una manera adecuada de salir de México y dejar que el país libremente pueda disfrutar de las instituciones que él mismo se dio", en Tamayo, Benito Juárez, 1972, t. X, pp. 290-291.

67 Benito Juárez a Pedro Santacilia, Paso del Norte, 26 de agosto de 1865 , en ibid., p. 179. 
Es importante sostener que Juárez no buscó un apoyo estadunidense más decisivo. No era conveniente para México y tampoco esperaba tal tipo de ayuda porque tales asistencias generaban estar en deuda con Estados Unidos, históricamente un asunto delicado. El reconocimiento estadunidense al gobierno de Benito Juárez resultaba esencial, para crearle un estatus que pudiera ser examinado por Gran Bretaña como por otros gobiernos europeos y debido a su posición estratégica en la frontera común.

Finalmente, al considerar la actitud que desde el principio de los años cincuenta fue asumida por el gobierno británico en los asuntos de México, Paul Knaplund ha revisado que durante la administración de Palmerston y después durante el tiempo de Gladstone, la política exterior de Gran Bretaña estuvo moldeada en la defensa real o supuesta de los intereses británicos. Este procedimiento no estuvo exento de cierto idealismo, porque se concebía que con la caída de los gobiernos tiránicos, ello daría por resultado el establecimiento de un sistema de Estados libres. La consecución de este plan podría beneficiar a la gente que vivía en aquellos países y al mismo tiempo podría servir para promover los intereses de los gobiernos europeos y el afianzamiento de una paz mundial. ${ }^{68}$ La intervención francesa y el establecimiento del Imperio de Maximiliano respondieron a este punto de vista que caracterizó las políticas desarrolladas por Gran Bretaña durante el siglo XIX.

${ }^{68}$ Knaplund, Gladstone's, 1970, p. 7.

\section{La caída del imperio}

El gobierno de Maximiliano informó a los enviados diplomáticos que, debido al conflicto militar, se pasarían los asientos de los poderes a la ciudad de Querétaro. El encargado de Negocios, Robert Middleton, declinó seguir al emperador más allá de la ciudad de México y se excusó de no guardar bajo su custodia objetos valiosos de Maximiliano. ${ }^{69}$ Lord Stanley, secretario de Relaciones, le respondió que el gobierno británico aprobaba su conducta. ${ }^{70}$ Maximiliano recibió de un diplomático inglés la misma respuesta que Benito Juárez había oído en 1863 de otro empleado británico. En ambos casos, la administración liberal republicana como el imperio habían sido reconocidos como gobiernos de México. En ambas ocasiones, el conflicto obligó a tales autoridades a abandonar la capital del país. Juárez comprendió la deslealtad sufrida por todos los partidos durante este periodo de tiempo (18611867) y confirmó su idea de una represalia en contra de aquellos intereses económicos, los únicos que realmente les importaban a las potencias y en particular a Gran Bretaña. Más aún, un castigo especial a las familias reales de Europa, a los monárquicos mexicanos y a toda aquella nación, partido e intereses financieros que estuvieron involucrados en promover la intervención armada en México.

69 Robert Middleton, Brasil 1847, Madrid 1850-1858, México 1864-1867 en The Foreign, 1865.

${ }^{70}$ Lord Stanley to Middleton, Londres, 30 de mayo de 1867, Fo:50.404.11. 
Maximiliano y sus generales, $\mathrm{Mi}$ guel Miramón y Tomás Mejía, fueron fusilados el 19 de junio de 1867. Estas ejecuciones siguieron a una serie de muertes entre republicanos e imperiales. Muchos más fueron ejecutados porque ambos regímenes promulgaron leyes castigando a todo aquel que fuera considerado como traidor, como prisionero de guerra o como reincidente. En Europa, los gobiernos, la prensa y la mayoría de la población culpó al gobierno republicano de México.

Juárez es de un tipo de raza, la cual desde la independencia de España siempre ha alternado entre el despotismo y la anarquía, y ahora está otra vez libre de seguir sus semisalvajes instintos. Como la mayoría de esos llamados mexicanos, Juárez es un indio sin ningún tipo de mezcla europea en la sangre. Él ha mostrado que tiene la energía, el coraje y la perseverancia, pero buscar en él piedad, caballerosidad con el enemigo caído y otras virtudes parecidas, ya sean cristianas o caballerescas sería fútil. Él pertenece a un partido cuya temeridad y desatención por la vida humana ha ensalzado al extremo lo salvaje del conflicto en los últimos cuatro años. Otra vez este partido representa a una población bárbara inclinada a mirar en la moderación y en la piedad como signos de debilidad. ${ }^{71}$

El resultado final de la intervención francesa generó una incorrecta evaluación del periodo y de las posibles consecuencias acerca de la viabilidad de México. La figura de Benito

${ }^{71}$ The Times, 2 de julio de 1867, microfilm en el Public Record Office, Londres.
Juárez, su empecinamiento y la singularidad de ser un presidente indio, constituía para toda la sociedad europea un motivo de desagrado, más que una mera curiosidad. El representaba todo aquello de lo que ese respetable periódico, indudablemente guía de la opinión pública victoriana, desconfiaba. Un triunfante republicanismo liberal en una época de un gobierno conservador en Inglaterra. Más aún, la victoria republicana aunada a la obtenida por las fuerzas de la Unión en Appomatox implicaba todo lo opuesto al proyecto imperial concebido por Disraeli. Finalmente, Juárez, indio por raza y mestizo de acuerdo a sus ideales y maneras, representaba un motivo de preocupación para el gobierno británico y para todo aquel imperio como el austriaco, controlando distintas gentes y naciones. Regímenes en cada momento de la historia, preocupados por una rebelión con connotaciones raciales y emancipadoras.

El triunfo republicano conseguido en junio de 1867 fue visto en aquel tiempo, y es considerado el día de hoy, como un asunto relevante:

Los historiadores ven atrás, en la violenta experiencia del Imperio de Maximiliano, como un punto de cambio. La historia moderna de México comienza con la victoria liberal de 1867 . En un sentido verdadero la república se convirtió en nación. ${ }^{72}$

Cada historiador que ha analizado el Imperio de Maximiliano ha coincidido en que los gobiernos europeos es-

${ }^{2}$ Meining, Shaping, 1993, vol. 2, p. 548. 
taban convencidos de que el emperador, su Estado Mayor y sus principales partidarios podrían salir libres y regresar salvos a Europa. Leyendo a la prensa de aquellos días, el fusilamiento produjo una gran impresión y las respuestas fueron desde un repudio como el editorial citado en The Times, las crónicas de lo que pasó cuando las noticias llegaron a la feria mundial en París, la reacción en Viena, así como los ásperos debates en la Cámara de los Comunes. ${ }^{73}$ Lord Stanley tuvo que responder a un número creciente de preguntas elaboradas por diversos representantes. Estos cuestionamientos eran una muestra de la diversidad de intereses involucrados, que iban desde "el asesinato de Maximiliano" hasta asuntos financieros reconocidos por el emperador. Se le interpelaba cuál sería la política oficial de Gran Bretaña relativa a toda la cuestión mexicana. Stanley expresó que era frecuente en América Latina que después de una guerra civil se produjese la ejecución de los líderes del bando contrario. Y subrayó un asunto muy importante: ¿debe esta Cámara debatir acerca de los méritos y las políticas de la expedición a México?, ¿debe examinar el estatus de Maximiliano y los derechos que tenía para ejercer el supremo poder en tal país?

¿Tenemos en todos estos casos que tomar nota en esta Cámara, y emitir un voto censurándolos? Si no se hace respecto de todos ellos, bajo qué principio podemos hacer una distinción. Nosotros somos el Parlamento del Reino Unido y no el Par-

73 Véase Conte, Maximiliano, 1944; Paso, Noticias, 1988. lamento del mundo. De ninguna manera somos responsables directa o indirectamente, por el lamentable suceso que ha ocurrido. ${ }^{74}$

En esta declaración, el secretario estaba evadiendo cuestiones esenciales acerca de la empresa que no solamente reunió a Francia y a Inglaterra como las dos potencias de la época, sino que fue considerada en Europa, Estados Unidos y la América del Sur como una intervención que podría cambiar el balance de poder internacionalmente. La problemática no era como Stanley la ponderaba, como otra revolución militar desarrollada en cualquier república de América Latina. La intervención francesa en México debe ser analizada como una estrategia europea con connotaciones imperiales que durante los años sesenta tuvo importantes consecuencias para las repúblicas de Santo Domingo, Perú y Chile. Estos tres países confrontaron invasiones extranjeras resultado de suspensiones en el pago de sus deudas, el asunto de las reclamaciones extranjeras, hasta la expedición de tinte colonialista llevada a cabo por España en la república caribeña. Más aún, la guerra de Secesión abrió las posibilidades para otra intromisión de las potencias europeas en América.

En su respuesta, Stanley eludió las bases en las que se apoyaba la intervención y el papel fundamental juga-

74 Sesión del Parlamento, lord Stanley responde a Lawrence Polk, 12 de julio de 1867, en Archivo Histórico de la Secretaría de Relaciones Exteriores de México (en adelante AltSREM), L-E2272, Handsard's Debates, vol. 188. 
do por Gran Bretaña. Él entendió que un debate parlamentario en los temas y criterios en los que se desarrolló el proyecto intervencionista, el estatus del emperador y los derechos para ejercer el poder en México hubieran desembocado en discutir las "Razones imperiales" esgrimidas y no explicadas por Palmerston en 1862. Lo anterior significaba examinar los compromisos con Napoleón III, aceptar las presiones ejercidas por los tenedores de bonos bien representados en el Parlamento y aceptar, con renuencia, que desde el principio del proyecto emergieron serias dudas sobre su idoneidad. El establecimiento de una monarquía en México había resultado en un completo fiasco, y para el momento de la discusión en el Parlamento, nada se había promulgado en México relativo a la suspensión de relaciones diplomáticas, ni respecto a la terminación de las convenciones en que se sustentaba el servicio de la deuda externa del país.

Las reservas expresadas por los miembros del Parlamento estaban en lo justo, pues debe recordarse que desde principios de los años sesenta, el discurso, las opiniones expresadas por la prensa y los procedimientos oficiales llevados a cabo por el gobierno británico, todos versaban sobre las razones que habían orillado a las potencias a desarrollar una intervención en México. Éstas eran, la ley que había establecido dos años en la suspensión del servicio de la deuda y las reclamaciones británicas como el asesinato, la confiscación de propiedades y la exigencia de préstamos forzosos en contra de súbditos británicos, todos estos problemas surgidos durante la guerra de Reforma.
En el caso concreto de los intereses británicos, el establecimiento del Imperio de Maximiliano se había materializado en dos créditos suscritos por súbditos de ese país. Los tenedores invirtieron comprando nuevos bonos debido a la conversión del Tratado de Miramar y muchos inversionistas cambiaron sus títulos de 1850-1851 por los nuevos bonos imperiales. Más aún, la empresa mexicana dio por resultado la fundación del primer banco moderno del país, los trabajos del primer ferrocarril en México y la negociación de un importante número de reclamaciones. Todas estas inversiones y la diversidad de intereses debían de ser defendidos por el gobierno de Gran Bretaña $y$, en este sentido, ellos necesitaban una respuesta contundente. Este estudio sostiene que fueron aquellos intereses económicos representados en el Parlamento los que, desde 1868 en adelante, presionaron al gobierno británico para que protegiera eficazmente sus inversiones y buscara la restauración de las relaciones diplomáticas con el gobierno de México.

Gran Bretaña era un imperio con intereses políticos y económicos alrededor del mundo. El Parlamento efectivamente no era del mundo, pero los súbditos británicos esperaban protección sobre aquellas inversiones que sustentaron un proyecto llevado a cabo por su gobierno. La declaración de Stanley posiblemente fue hecha como consecuencia de una insularidad típicamente inglesa que seguramente disgustó al primer ministro Disraeli, inmerso en afanes imperialistas muy del agrado de la reina Victoria. Lo dicho por Stanely era una actitud que segu- 
ramente habría dejado perplejos a los políticos de Estados Unidos, quienes a pesar de un fingido aislamiento decimonónico, han creído que ellos y su país tienen la misión de imponer modelos y salvar al mundo de aquellos que no los comparten. ${ }^{75}$ Finalmente, lord Stanley sostenía su objeción en precipitar una renovación de las relaciones diplomáticas con el gobierno republicano de México. Sin embargo, se oponía a una permanente suspensión de la relación bilateral, "las objeciones son muy obvias: yo creo que el principal negocio de un ministro británico en México es el de urgir a tal gobierno a que examine las distintas reclamaciones". ${ }^{76}$

En necesario resaltar que el secretario de Relaciones, y probablemente el gobierno británico, no entendieron las profundas implicaciones de la victoria juarista. Peor aún, las ideas finales de Stanley eran iguales a las de lord Russell urgiendo a Charles Wyke y a Peter Scarlett que la Deuda de Londres, la Convención Inglesa y las reclamacio-

75 "Los americanos siempre han considerado a su país como moralmente superior a otros[...] todos los americanos conocen que tienen la sagrada misión de preservar sus instituciones y de ser el faro de esperanza para toda la humanidad[...] Los países continentales de Europa y, de cierta manera, en menor sentido la Gran Bretaña, eran el viejo mundo, con énfasis en la connotación despectiva de la palabra viejo. Sus monarquías feudales, sus estériles aristocracias, sus estancadas tradiciones, su sociedad estructurada en clases sociales, su rígida economía, no ofrecía modelo alguno para Estados Unidos", en Campbell, Transformation, 1976, pp. 1-2.

76 AHSREM, L-E-2272, Handsard's Debates, vol. 188,1867 . nes británicas eran el único asunto relevante de la relación bilateral. Lo anterior significaba que no importaba si la Gran Bretaña había reconocido a las administraciones conservadoras asentadas en la ciudad de México y al mismo tiempo estaba negociando el servicio de la deuda con el gobierno liberal de Veracruz (1858-1860). Tampoco importaba que el gobierno de Juárez hubiese reconocido la totalidad de la deuda mexicana como resultado de presiones diplomáticas y presencia militar. Más aún, no era digno de ser tomado en cuenta que el gobierno constitucional hubiera permitido que oficiales británicos administrasen las aduanas mexicanas, lo cual constituía una flagrante violación a la soberanía del país. En 1862 el gobierno juarista respondió y aceptó todas las demandas británicas, pero Palmerston rechazó la Convención de Puebla, porque en ese momento su gobierno estaba dedicado a buscar el mejor medio para cambiar el sistema de gobierno en México. Peor aún, no importaba que Maximiliano hubiese reconocido la totalidad de la deuda mexicana, contratado nuevos créditos con bancos ingleses y hubiese facilitado la entrada de inversiones británicas como la fundación y el desarrollo del Banco de Londres y México. La Legación británica no quiso proteger valores personales, esto era un asunto de delicadeza dado el estado en que se encontraba el emperador antes de su salida a Querétaro.

Para el gobierno de su majestad británica, Maximiliano había sido ejecutado y ello se debía al carácter semisalvaje de los mexicanos. Gran Bretaña en "ningún sentido era responsable" de tal 
acontecimiento. La discusión en el Parlamento, en julio de 1867, era otra vez las deudas y las reclamaciones británicas en contra de México. No importaba cuál era el gobierno mexicano, las víctimas, los aliados o los compromisos adquiridos durante la intervención. El gobierno británico y su secretario de Relaciones, Stanley, estaban concibiendo exigir el cumplimiento de los acuerdos reconocidos por Maximiliano al gobierno republicano que ellos mismos, en 1861, habían considerado como inexistente y sin autoridad para regir al país; más aún, lo señaló como carente de personalidad para entrar en tratos, sobre todo si involucraban a varios países. Todo este curso de acciones revela una completa inmoralidad en los procedimientos británicos de política exterior, un asunto jamás reconocido por la historiografía de aquel país.

\section{La postura juarista}

El último segmento de este artículo pone atención al proceso de declaraciones presidenciales y la proclamación de políticas soberanas que definieron el triunfo republicano. En un periodo de seis meses, el gobierno mexicano estableció su posición oficial frente a las potencias que reconocieron al Segundo Imperio. Este era un plan que había sido madurado a lo largo del tiempo de la intervención y su aplicación respondía a las acciones y presiones desarrolladas por los diplomáticos extranjeros y por los acreedores de México durante la segunda mitad de 1867.

En julio, al entrar el presidente Juárez y sus ministros a la ciudad de
México, éste pronunció un discurso para explicar la importancia de la victoria republicana y el significado de la nueva situación política. Señaló una serie de conceptos para que fueran tomados en cuenta por los diplomáticos extranjeros y por aquellos europeos con intereses económicos en el país. Juárez sostuvo lo siguiente: el gobierno republicano ba observado como primero de su deberes no contratar ningún acuerdo, en México o en el exterior, que pudiera dañar la independencia de la nación, la integridad de su territorio o en contra del orden constitucional. El gobierno siempre se mantuvo dentro del territorio nacional, siempre existió y se rigió inequívocamente de acuerdo a las leyes promulgadas por el pueblo de México, e insistió: para completar el triunfo republicano el gobierno no llevará a cabo actos vengativos, pero necesita ejercitar la justicia para garantizar la paz y la legalidad, condiciones esenciales para la prosperidad de México. ${ }^{77}$

Tres juicios importantes resaltan del mencionado discurso. El primero era una directa imputación a los créditos contratados por Maximiliano, sumas de dinero imposibles de ser cubiertas puntualmente y que tarde o temprano resultarían en acciones en contra de la integridad de la república. La segunda nota respondía a una preocupación del presidente, subrayar que su gobierno continuó existiendo todo el tiempo de la intervención, actuando dentro de los límites territoriales del país y que todas sus acciones habían tenido como marco legal las facultades

77 "Proclama del presidente Juárez a los mexicanos", en Fo.50.407.32 
extraordinarias que le habían sido conferidas por el Congreso. Las dos últimas cuestiones eran importantes para internacionalmente argumentar la ilegalidad del imperio y negar la obligatoriedad de sus compromisos. En este sentido, la existencia jurídica del régimen republicano había sido la base para el reconocimiento otorgado por el gobierno de Washington. La tercera nota respondía a los conceptos expresados por Jesús Terán y porque el presidente, sus ministros y los partidarios republicanos estaban convencidos de que México, en 1867, demandaba tranquilidad y prosperidad, ambas condiciones eran imposibles de conseguir si todos los intereses que habían apoyado al Imperio de Maximiliano continuaban libres de cualquier castigo. Los republicanos tenían como referente los traumáticos acontecimientos de 1861 que culminaron con el desembarco de tropas españolas en diciembre de ese año. El establecimiento del Segundo Imperio era el resultado de un triunfo a medias.

De julio a diciembre el triunfo republicano se tradujo en una serie de medidas que afectaron muchos intereses. Robert Middleton, cónsul en la ciudad de México, informaba al Foreign Office acerca de las "ultrademocráticas y posiblemente socialistas opiniones" proclamadas por Sebastián Lerdo de Tejada. Al mismo tiempo daba cuenta de un préstamo voluntario al gobierno de Juárez promovido por distintas casas mercantiles, por distintos tenedores de bonos, por el Banco de Londres y México y por el cónsul prusiano. Informaba que en aquellos días un agente del Banco Rothschild había llegado a la capital y había declarado que esta institución no había promovido ningún acuerdo financiero con el caído imperio. Después el diplomático inglés subrayó el hecho de que los ministros de Italia, Francia, Austria, Bélgica y España habían solicitado al gobierno mexicano sus pasaportes; una situación totalmente distinta con la del cónsul estadunidense que había sido nombrado ministro plenipotenciario. Middleton expresó que las autoridades mexicanas consideraban tal petición de los diplomáticos europeos como una protesta por el fusilamiento de Maximiliano llevado a cabo por el régimen republicano. La respuesta elaborada por el ministro Lerdo de Tejada era que México no solamente facilitaba la salida de los ministros plenipotenciarios, sino que desconocía el carácter oficial de todos aquellos encargados de negocios, cónsules y vicecónsules apostados a lo largo de la república, cuyos gobiernos por sí mismos se habían puesto en un estado de hostilidad en contra del gobierno republicano, y establecieron relaciones con el llamado imperio. ${ }^{78}$

El decreto oficial de agosto de 1867 ha sido identificado en este estudio como la segunda ruptura de relaciones diplomáticas entre México y las

${ }^{78}$ Middleton a Stanley, México, 19 y 27 de julio y 10 de agosto de 1867 , en F(0.50.407.3537. Sebastián Lerdo de Tejada a Midddleton, México, 20 de agosto de 1867 en British, 1873, pp. 685-86. El cónsul británico estaba en la ciudad de México, vicecónsules antes de agosto de 1867 estaban localizados en Guanajuato, Real del Monte, San Luis Potosí, Zacatecas, Tepic, Mazatlán, Tampico, Matamoros, Veracruz, La Laguna, Mérida y Orizaba. 
potencias europeas. En julio de 1861, Charles Wyke y Dubois D'Saligny, rompieron relaciones con la administración juarista y, seis años después, ese mismo gobierno argumentaba que de tiempo atrás no existía relación alguna entre aquellas naciones y la república. Lord Stanley sostuvo que la decisión mexicana no era compatible con la dignidad del gobierno británico, que era contraria al derecho internacional y que la situación ameritaba liquidar todo lo parecido a una misión diplomática.

Es importante sostener que, de acuerdo con los despachos oficiales, correspondencia privada e información aparecida tanto en la prensa británica, como en la mexicana, todos estaban convencidos de que la ruptura sería un corto impasse. Los intereses envueltos en este asunto tenían su propia interpretación del por qué se había llegado a tal punto. Algunos pensaban que después de un tiempo de radicalismo, el mismo gobierno de México iniciaría negociaciones para restaurar las relaciones diplomáticas, otros consideraban que la administración de Juárez no sería capaz de manejar al país y que muy pronto otra "revolución" acabaría con él. La mayoría, incluyendo al propio gobierno inglés, contemplaban la importancia del comercio, de la propiedad británica en México y el asunto de la deuda externa del país como la mejor ruta que los dos países tenían para en poco tiempo normalizar la situación. Nadie en ambos lados del Atlántico pudo sospechar que el distanciamiento duraría tantos años. El impasse desde la óptica republicana duró con España diez años (de 1861 a
1871), con Francia persistió por 19 años (de 1861 a 1880) y con Gran Bretaña 23 años (de 1861 a 1884). Tomando en consideración el tiempo perdido puede decirse que los acreedores, los gobiernos europeos y los mexicanos, la república y todos aquellos partidos comprometidos en la aventura imperial perdieron algo, pero en diferentes proporciones y en asuntos de distinta índole. El restablecimiento de las relaciones diplomáticas entre México y las potencias europeas se definió por el cambio en los gobiernos, tanto de aquí como de allende el Atlántico.

Meses más adelante, Middleton informó que en conversaciones particulares se le había insinuado que los tratados, acuerdos y convenciones reconocidas por Maximiliano no tenían ninguna validez para el gobierno republicano. Después envió a Londres un recorte del periódico liberal y semioficial El Siglo Diez y Nueve escrito por Francisco Zarco, en el cual se establecía que la invasión extranjera por sí misma había terminado con los antiguos tratados que México tenía con las potencias europeas. El autor subrayaba que simplemente el hecho del triunfo republicano terminaba, con el tiempo, en que las potencias reconocían cada gobierno de facto y presionaban a cada administración con reconocer verídicas o supuestas reclamaciones que al final eran protegidas por las convenciones diplomáticas. Advertía que si las potencias continuaban presionando por obtener compensaciones de viejas reclamaciones, la nación mexicana también demandaría reparaciones a los gobiernos europeos por su decidido apoyo a un régimen que había hecho la 
guerra a la mayoría del pueblo mexicano, dañando la soberanía de la nación, la propiedad y la vida de muchos de sus ciudadanos. ${ }^{79}$

Desde julio de 1867 hasta diciembre, la administración republicana comenzó un programa que contemplaba cambios en la organización política. La última reforma importante del año era el problema del país: el servicio de la deuda externa y el asunto de las reclamaciones extranjeras. Las ideas propuestas con dos años de antelación por Jesús Terán se transformaron en una política oficial del Estado mexicano, llamada por la historiografía como la Doctrina Juárez o Republicana.

La declaración no solamente involucraba a las potencias que reconocieron al imperio, sino que era una plataforma de principios; origen de una doctrina que debía ser comprendida por los gobiernos europeos interesados en reanudar relaciones diplomáticas con México, también como principios que al ser considerados como requisitos debían ser manejados por diplomáticos mexicanos y europeos en las posibles negociaciones para restablecer relaciones bilaterales. Finalmente, eran conceptos que debían ser entendidos y defendidos cuando las mismas autoridades de la república quisieran proteger los intereses nacionales de presiones externas, o cuando como resultado de problemas de política interior o dificultades financieras, se vieran tentados a contradecir tales principios de política soberana:

79 "Los extranjeros", El Siglo Diez y Nueve, 14 de septiembre de 1867, en FO.50.407.42.
A causa de la intervención, quedaron cortadas nuestras relaciones con las potencias europeas. Tres de ellas, por virtud de la Convención de Londres se pusieron en estado de guerra con la república. Luego, la Francia sola continuó la empresa de la intervención, pero después reconocieron al llamado gobierno, sostenido por ella, los otros gobiernos europeos que habían tenido relaciones con la república, a la que desconocieron, separándose de su condición de neutralidad. De este modo, esos gobiernos rompieron sus tratados con la república y han mantenido y mantienen cortadas con nosotros sus relaciones. $L a$ conducta del gobierno de la repuiblica ba debido normarse en vista de la de aquellos gobiernos. Sin haber pretendido nada de ellos, ha cuidado de que no se haga nada que pudiera justamente considerarse como motivo de ofensa y no opondrá dificultad para que en circunstancias oportunas puedan celebrarse nuevos tratados bajo condiciones justas y convenientes, con especialidad en lo que se refiere a los intereses del comercio. ${ }^{80}$

Cuando se analizan los conceptos expresados en la declaratoria de Benito Juárez, la reacción en México como en Europa fue similar a aquellas expresiones y demandas que se produjeron en 1861 , cuando se conoció la ley que suspendía el servicio de la deuda mexicana por dos años. Los tenedores de bonos de Londres como de la Convención Inglesa consideraron el edicto me-

80 "Discurso pronunciado por el presidente de la república en la apertura del Congreso de la Unión", 8 de diciembre de 1867 , en Fo.97.282. Véase Tamayo, Benito Juárez, 1972, vol. 12, p. 889 (las cursivas son mías). 
xicano como monstruoso y contrario tanto a los principios del derecho internacional como al derecho público. Sin embargo, la situación en 1867 era diferente. Sebastián Lerdo de Tejada tuvo una entrevista con Middleton y le expresó que la posición de México tenía por bases las mismas doctrinas jurídicas que Gran Bretaña aplicaba internacionalmente. Lerdo le señaló cuáles eran las razones por las que los tratados, aun en perpetuidad, podían expirar: cuando una de las partes contratantes pierde su existencia como Estado independiente; cuando la constitución interna del otro Estado ha cambiado y hace el tratado inaplicable, y cuando los partidos contratantes entran en guerra. "Francia y España, nos imaginamos, no estarán soñando en reclamar todavía la permanencia de sus tratados. Lo está Inglaterra."81

$\mathrm{El}$ presente artículo argumenta que en la opinión del ministro Lerdo, y de acuerdo con su interpretación de los principios jurídicos de la época, la guerra de Intervención modificó la relación entre México y aquellos países que moral y financieramente apoyaron al imperio. En este sentido, los tratados bilaterales que México tenía con las potencias europeas terminaron al ser invadido el país por Francia y, por tanto, la pérdida de su independencia. El llamado Imperio de Maximiliano reconocido por Gran Bretaña era francés, no tenía autonomía y no representaba los deseos del pueblo mexicano. La guerra como una cuestión de hecho, suspendió las relaciones diplomáticas

81 Lerdo a Middleton, México, 11 de diciembre de 1867, en Fo.50.408.10. con el gobierno constitucional de México y alteró la naturaleza de los tratados bilaterales. Más aún, era el triunfo republicano el que proveía de las bases legales para revisar los acuerdos que México tenía con otros países.

Para terminar con esta última sección queremos exponer los principios jurídicos en que fue instituida la Doctrina Republicana, porque tal declaración definió las relaciones bilaterales con Gran Bretaña por cerca de dos décadas. Primero hay que tratar con los razonamientos decimonónicos utilizados por las partes involucradas. En este sentido resulta esencial analizar el trabajo de Henry Wheaton, un renombrado abogado británico citado al mismo tiempo por los acreedores de México, por el departamento jurídico del Foreign Office y por las autoridades mexicanas. Las dos últimas partes, abogados de profesión, legalistas en sus procedimientos y en la interpretación del panorama internacional, estaban convencidos de que la estricta observación de la ley era, para ese momento, el procedimiento más adecuado y el menos peligroso para en un futuro llegar a un acuerdo sobre las problemáticas que involucraban a México con las naciones europeas.

Wheaton señalaba que los efectos internacionales producidos por el cambio de la persona en quien recaía la soberanía, o por el cambio en la forma de gobierno de cualquier Estado, se resumían de la siguiente manera:

respecto a sus tratados de alianza y comercio, a su deuda pública, a su dominio público y a los derechos privados de propiedad, así como a los daños y perjuicios 
hechos al gobierno o a los ciudadanos de otro Estado. ${ }^{82}$

Wheaton afirmaba que los juristas de los siglos XVII y XVIII habian dividido los tratados en personales y temáticos. Los primeros se refieren exclusivamente a las personas que celebran el tratado. Los segundos se refieren a la materia-asunto de una convención, forzando la intervención del Estado, a pesar de los cambios que tuvieran lugar en su constitución interna o en la de sus gobernantes. ${ }^{83}$ El abogado inglés resaltaba que debía admitirse que ciertos cambios en la constitución de una de las partes contratantes, o en la persona en la cual recaía la soberanía tenía el efecto de anular los tratados preexistentes. Sin embargo, al mismo tiempo consideraba una cuestión esencial: los tratados no se fundan meramente en el contrato mismo, sino en relaciones mutuas que los han llevado a concertar ciertos acuerdos. Esta última precisión debe ser considerada como el argumento llevado adelante por los diplomáticos británicos y mexicanos que a lo largo de varias décadas habían negociado diversas convenciones. Sin embargo, la interrupción unilateral por parte de los representantes de Gran Bretaña y Francia, en 1861 , no tomó en cuenta esa relación histórica. En 1864 Terán intentó explicarle a John Russell que no solamente ligaban a los dos gobiernos los tratados existentes, sino que México reconocía los derechos genuinos que tenían los acreedores. Esta relación

82 Wheaton, Elements, 1904, pp. 45-48.

83 Ibid. histórica había generado privilegios y obligaciones a las partes involucradas.

Continuando con su razonamiento, Wheaton concedía que una excepción que libera un acuerdo de su obligatoriedad es cuando, debido a un cambio en la organización social del Estado o una modificación importante en su soberanía, ambos dan por resultado la interrupción de la relación bilateral. En este sentido los tratados dejan de existir. Sin embargo apuntaba una importante controversia:

Referido a sus deudas públicas -aun de un Estado revolucionado- el mero cambio de la forma de gobierno o en la persona que rige, no afecta la obligación de pagar[...] Las deudas contratadas a nombre del Estado, por sus agentes autorizados y para su uso público, la nación continúa responsable de ellos, no importando el cambio en su constitución interna. ${ }^{84}$

Si el presente estudio coincide con que la guerra de Intervención modificó la relación diplomática y la naturaleza de los tratados, los argumentos jurídicos de Wheaton proveen de otros conceptos para el debate que en los años sesenta involucró a todos los intereses concernientes en los asuntos mexicanos. Cuando el autor dividió los tratados en personales y temáticos, el debate se dirigió al carácter de las partes contratantes y al de la naturaleza de los créditos. Son tratados temáticos los contrarios a la esclavitud, los acuerdos comerciales y los contratos referentes a

${ }^{84}$ Ibid. 
una deuda soberana. En este sentido, desde 1824 hasta 1862 la deuda mexicana de Londres, el Tratado de Amistad Comercio y Navegación de 1826, la Convención Inglesa de 1851, y las convenciones diplomáticas de 18591860 , todos ellos deben ser considerados como tratados temáticos. Es importante señalar que independientemente de los levantamientos militares, de las modificaciones constitucionales y de las guerras internacionales, de acuerdo a derecho, los distintos gobiernos mexicanos reconocieron los montos de la deuda de Londres como las deudas convencionadas con Inglaterra, Francia, España y Estados Unidos. Las suspensiones de pago y las convenciones forzosas durante la guerra de Reforma no alteraron las obligaciones que México tenía con sus acreedores y tampoco modificaron los derechos que éstos habían adquirido. Sin embargo, la deuda imperial (1864-1867) fue concebida como una serie de préstamos de carácter personal entre Maximiliano, los banqueros ingleses y franceses y los tenedores de bonos mexicanos. La deuda del imperio era personal y además reconocía el monto de las deudas mexicanas y los derechos de los acreedores. Estas condiciones eran esenciales para que los intereses financieros apoyaran el establecimiento de un gobierno monárquico, lo que significaba un verdadero cambio en el sistema político de México. Por otro lado, algunos créditos fueron concebidos para recuperar seis años de gastos militares y para combatir a un régimen que al final de cuentas ganó la guerra.

El gobierno británico, los financieros de aquel país, las autoridades na- poleónicas y los banqueros franceses ayudaron a cambiar el sistema de gobierno en México. Estaban convencidos de que un monarca legítimo era la figura adecuada para organizar al país para cumplir con los ya antiguos tratados bilaterales referidos a la deuda y al pago puntual de ésta. Teniendo como base dicho plan, los gobiernos y los acreedores estuvieron de acuerdo en otorgar créditos en su modalidad de contratos privados. Los préstamos otorgados a Maximiliano, el establecimiento de una monarquía como un sistema distinto de gobierno, la guerra de intervención y en particular el triunfo republicano, fueron asuntos que, como cambios significativos, eran razón suficiente para anular los contratos preexistentes.

Más aún, y siguiendo el mismo razonamiento de Wheaton: las deudas públicas debían ser requeridas por el Estado y por sus agentes autorizados teniendo como fin el bienestar público. En este sentido, desde 1864 los agentes mexicanos en Europa, los mencionados Terán y Escobar, abiertamente habían declarado la ilegalidad de las bases y el proceso de los préstamos organizados en Londres y París. Los dos agentes republicanos resaltaron que el propósito de tales préstamos era beneficiar a una sola persona y para cubrir considerables gastos de guerra. Aquellos enormes créditos no beneficiaban en manera alguna a México y al mismo tiempo advirtieron a los tenedores de bonos de la Deuda de Londres y de la Convención Inglesa de que como resultado del Tratado de Miramar, estaban modificando sus legítimos derechos reconocidos por todas las admi- 
nistraciones mexicanas. La anterior era una situación positiva de acuerdo con la jurisprudencia.

Siguiendo el debate acerca de la existencia de la deuda mexicana reconocida hasta 1863 por los gobiernos republicanos, el carácter de la deuda imperial, las implicaciones de tales préstamos y finalmente el repudio republicano de 1867 , son cuestiones que llevan a este estudio a considerar la opinión de Edwin Borchard en su trabajo acerca de las dificultades financieras experimentadas por los Estados soberanos, los principios jurídicos y los mecanismos utilizados por los acreedores para defender sus intereses y obtener pronto pago.

El desconocimiento de una deuda constituye la negativa en admitir el carácter obligatorio de aquélla[...] el desconocimiento se puede extender a toda la deuda o a parte de ella o a sus términos contractuales $[\ldots]$ Los desconocimientos han sido comunes después de revoluciones, cuando un nuevo gobierno desconoce las obligaciones contratadas por cualquier anterior gobierno ya fuese de jure o de facto. Las razones alegadas son de que el régimen anterior no tenía autoridad alguna para atar a la nación. Los ejemplos más característicos han sido: Portugal declina las deudas contratadas por don Miguel en 1832, México declina las deudas contratadas por Maximiliano 18641866 y los bonos B, C, D, de Victoriano Huerta en 1913. La Unión Soviética declina la deuda zarista. ${ }^{85}$

85 Borchard, State, 1951, p. 129. Este trabajo junto con el escrito por el colega de Borchard, William Wynne y el contratado por el Consejo
El gobierno de Juárez repudió la deuda solicitada y reconocida por Maximiliano, porque era impagable y porque admitir los actos del emperador involucraba reconocer muchos asuntos distintos a la deuda misma que maniataban y comprometían a cualquier gobierno republicano. Sin embargo, a pesar del triunfo republicano, la deuda mexicana anterior a 1862 continuó teniendo una legítima existencia, pero ya no fue considerada como un asunto resultante de convenciones diplomáticas, por definición un asunto que involucraba a Estados soberanos. La guerra de Intervención y el triunfo republicano generaron una nueva situación jurídica y la necesidad de establecer nuevos tratados.

No sobra insistir en que fue la victoria republicana la que cambió el status quo y abrió la posibilidad de imponer una plataforma de principios y acciones. Esta situación fue progresiva, pero completamente entendida por los gobiernos de Gran Bretaña, Francia, España, Bélgica y Austria. Ninguno de ellos presionó por una inmediata represalia, tampoco por otra inter-

de Tenedores de Bonos Extranjeros en 1886, que sirvió como base para las negociaciones bilaterales para establecer las deudas de México, escrito por E. Kozhevar, son considerados en este artículo como los mejores trabajos que analizan la deuda del país. Sin embargo, es necesario resaltar que ninguno de los mencionados autores interpretando diversos principios jurídicos y números sobre la deuda consideró lo importantes que eran para tal asunto los problemas políticos al interior de México y la relación de éste en el ámbito internacional. Ambas situaciones condicionaron el servicio de la deuda y las convenciones diplomáticas sobre la deuda exterior del país. 
vención militar o aun, el aislamiento comercial en contra de México. Lo anterior contrastaba con la de la Bolsa de Londres y otras bolsas europeas que de nueva cuenta cerraron sus puertas a posibles préstamos que tuvieran como destino la república mexicana.

Como resultado de la aplicación de la Doctrina Republicana, el gobierno británico se pronunció por la no protección oficial a los tenedores de bonos en sus negociaciones con las administraciones mexicanas, ello representó el fin de las convenciones diplomáticas en torno a la deuda y el inicio de negociaciones directas entre México y el Consejo de Tenedores de Bonos Mexicanos. En otro sentido, a pesar de las recriminaciones publicadas en la prensa y de las acusaciones durante los debates parlamentarios en Londres, a partir de 1868 y durante los setenta y ochenta, una nueva generación de inversionistas británicos, distintos a los acreedores, continuaron comerciando y abriendo nuevas áreas de inversión. Éstos eran una categoría distinta de inversionistas ingleses en México, con intereses más modernos y muchas veces opuestos a las presiones ejercidas por los llamados London and Convention bondholders.

\section{ARCHIVOS}

AHSREM Archivo Histórico de la Secretaría de Relaciones Exteriores de México

Archivo Histórico del Royal Bank of Scotland

Fo Foreign Office

HC Baring House Correspondence

\section{BIBLIOGRAFÍA}

-Bagehot, Walter, The Collected Works of Walter Bagehot. The Economic Essays, The Economist, Londres, 1978, vol. 10.

-Baring Brotbers, Merchant Banking Today, Baring Eds., Londres, 1970.

-Baster, A. J., The International Banks, P. S. King, Londres, 1935.

-Bátiz, José Antonio, "Aspectos financieros y monetarios (1821-1880) en Ciro Cardoso, México en el siglo XIX, Ed. Nueva Imagen, México, 1983.

-Blow Williams, Judith, British Commercial Policy and Trade Expansion, 1750-1850, Clarendon, Oxford, 1972.

-Borchard, Edwin, State Insolvency and Foreign Bondbolders. General Principles, Yale University Press, New Haven, 1951.

-British Foreign and State Papers 1867-68, vol. IVIII, William Ridway, Londres, 1873.

-Bulnes, Francisco, El verdadero Juárez y la verdad sobre la intervención y el imperio, Bouret, México, 1904.

- La deuda inglesa. Artículos publicados en el periódico El Siglo Diez y Nueve, Miguel Ángel Porrúa/somex, México, 1990.

-Cain, P. y A. Hopkins, British Imperialism and Expansion 1688-1914, Longman, Londres, 1993.

-Campbell, Charles S., The Transformation of American Foreign Relations, 1865-1900, Harper \& Row, EUA, 1976.

-Case, Lyn y Warren Spencer, The United States and France: Civil War Diplomacy, University of Pennsylvania Press, Filadelfia, 1982.

-Conte Corti, Egon Caesar, Maximiliano y Carlota, Fondo de Cultura Económica, México, 1944.

-Chapman, Stanley, The Rise of Merchant Banking, Allen y Unwin, Londres, 1984.

-Dougherty, John, "Gran Bretaña y la intervención francesa", Historia Mexicana, El 
Colegio de México, núm. 14, 1964-1965, México.

-Emden, Paul H., Money Powers of Europe in the 19th and 20th century, Sampan, Low \& Marston, Londres, 1937.

-Fulford, Roger, Glyn's 1753-1953. Six generations in Lombard Street, Mc Millan, Londres, 1953.

-Galeana, Patricia, Las relaciones IglesiaEstado durante el Segundo Imperio, IIH-UNAM, México, 1991.

-Gille, Genevieve, "Los capitales franceses y la expedición a México", Revue d" Historie Diplomatique, vol. 69, 1965, citado en Leonor Ludlow y Carlos Marichal, Un siglo de deuda pública en México, Instituto Mora/ COLMICH/COLMEX/Instituto de Investigaciones Históricas-Unam, México, 1998.

-Gore-Browne, P., The History of the House of Glyn, Mills $\&$ Co., private edition, Londres, 1933.

-Goschen, vizconde, Essays and addresses on Economic Questions 1865-1893, Edward Arnold, Londres, 1905.

-Hamnett, Brian, Juárez, Longman, Gran Bretaña, 1994.

-Jones, Charles, "Commercial Banks and Mortgage Companies” en D. C. M. Platt, Business Imperialism 1840-1930. An inquiry based on British Experience in Latin America, Clarendon Press, Oxford, 1977.

-Kennedy, Paul, The realities Behind Diplomacy: Background Influences on British External Policy, 1865-1980, Allen and Unwin, Londres, 1981.

-Knaplund, Paul, Gladstone's Foreign Policy, Frank Cass, Londres, 1970.

-Kozhevar, E., Report on the Republic of Mexico to the Councit of Foreign Bondholders, Containing a Collection of Financial Statistical and General Information Compiled from Official Sources, Wertheimer, Londres, 1886.
-Ludlow, Leonor, "La disputa financiera por el Imperio de Maximiliano y los proyectos de fundación de instituciones de crédito (1863-1867)", Historia Mexicana, núm. 188, abril-junio de 1988.

-Manero, Antonio, La revolución bancaria en México. Una contribución a la bistoria de las instituciones de crédito en el país, Talleres Gráficos de la Nación, México, 1957.

-McAleb, Walter, Present and Past Banking in Mexico, Harper \& Brothers, USA, 1920.

-Meining, Donald, The Shaping of America. A Geographical Perspective on 500 years of History. Continental America 1800-1867, Yale University Press, New Haven, 1993, vol. 2.

-Nava, Guadalupe, "Origen y monto de la deuda pública en 1861" en Leonor Ludlow y Carlos Marichal, Un siglo de deuda pública en México, Instituto Mora, México, 1998.

-Orbell, John, "George H. White" en Viajeros europeos del siglo XIX en México, Fondo Cultural banameX, México, 1996.

$\longrightarrow$, Baring Brotbers: A History to 1939, Baring Eds., Londres, 1985.

-, Guide to the Baring Archive at ING/Baring, Baring Eds, Londres, 1997.

-Ortiz de Montellano, Mariano, Apuntes para la liquidación de la deuda contraida en Londres, Imprenta del Gobierno Federal, México, 1886.

-Paso, Fernando del, Noticias del Imperio, Diana, México, 1988.

-Payno, Manuel, Cuentas, gastos, acreedores $y$ otros asuntos del tiempo de la intervención francesa y del imperio, 1861-1867, Secretaría de Hacienda y Crédito Público, México, 1981.

-Platt, D. C. M., Finance, Trade and Politics in British Foreign Policy, 1815-1914, Clarendon Press, Oxford, 1968.

-Presnell, L. S. y John Orbell, A guide to the Historical Records of British Banking, Gowe-Grafton, Londres, 1985. 
-Quirarte, Martín, Historiografía sobre el Imperio de Maximiliano, IIH-UNAM, México, 1993.

-Roeder, Ralph, Juárez y su México, Fondo de Cultura Económica, México, 1984.

-Rowsley, Judith, Going for Broke. The collapse of Baring, Harper-Collins, Londres, 1996.

-Secretaría de Hacienda y Crédito Público, La vieja deuda titulada de México, SHCP, México, 1963.

-Sierra, Justo, Juárez, su obra y su tiempo, UNAM, México, 1977.

-Strange, Susan, "Finance and capitalism: the City's imperial role yesterday and today", Review of International Studies, vol. 20, núm. 4, 1994.

-Tamayo, Jorge L., Benito Juárez, discursos $y$ correspondencia, Secretaría de Patrimonio Nacional, México, 1972, vols. 8 y 9.

-Tenenbaum, Barbara, "Mexico's money market and the internal debt" en Reinhard Liehr, The public debt in Latin America in bis- torical perspective, Vervuert-Iberoamericana, Frankfurt, 1995.

-The Foreign Office List. Forming a Complete British Diplomatic and Consular Handbook, Harrison, Londres, 1865.

-Tischendorf, Alfred, "The Anglo-Mexican claims comission 1894-95", Hispanic American Historical Review, núm. 37, 1957.

-Trueblood, Beatrice, 125 años de la Banca Serfin, Serfin Edits., México, 1990.

-Turlington, Edgar, Mexico and $\mathrm{Her} \mathrm{Fo-}_{\mathrm{O}}$ reign Creditors, Columbia University Press, Nueva York, 1930.

-Vigil, José Ma., México a través de los siglos. La Reforma, Edit. Cumbre, México, 1981, t. IX.

-Wheaton, Henry, Elements of International Law, Stevens \& Sons, Londres, 1904.

-Wynne, William y Edwin Borchard, "Foreign Bondholders Protective Organizations", Yale Law Journal, Yale University Press, 1933, New Haven.

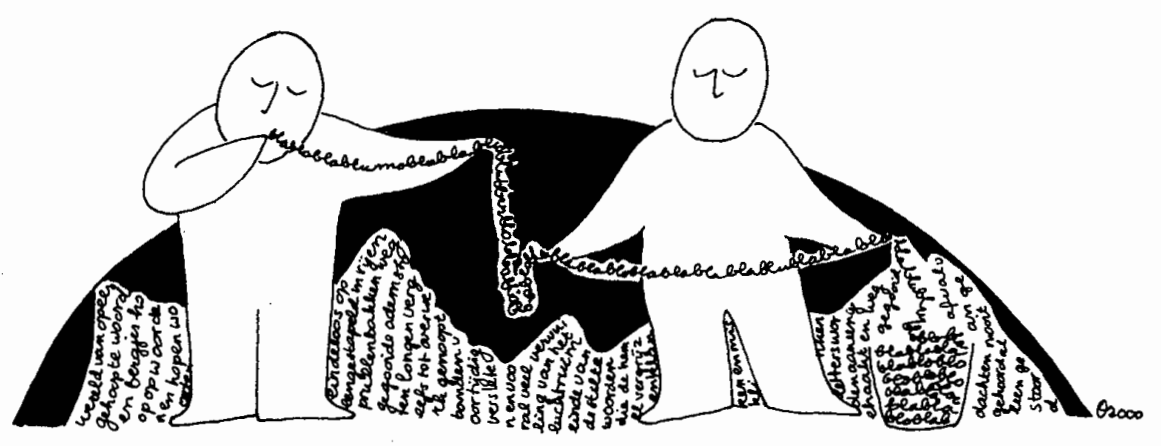

La Deuda Imperial y la Doctrina Republicana 